\title{
Hubungan antara Kelekatan Pemuda-Orang Tua dan Dukungan Iman Orang Tua dengan Religiositas Intrinsik pada Pemuda Gereja-Gereja Injili di Bandung
}

\section{The Relationship Between Parental Attachment and Faith Support with Intrinsic Religiosity of Emerging Adults from Evangelical Churches in Bandung}

\author{
Linda Christine Setiawati, ${ }^{1)}$ Aileen P. Mamahit, ${ }^{2) *}$ Sylvia Soeherman, ${ }^{2)}$ \\ 1) Program Studi Magister Teologi Sekolah Tinggi Teologi SAAT, Malang \\ 2) Sekolah Tinggi Teologi SAAT, Malang \\ *) Korespondensi: aileen.mamahit@seabs.ac.id
}

\begin{abstract}
Abstrak: Penelitian ini bertujuan untuk menemukan jawaban atas pertanyaan penelitian, yaitu ada atau tidaknya hubungan antara kelekatan pemuda-orang tua dan dukungan iman orang tua dengan religiositas intrinsik pada pemuda di gereja-gereja Injili di Kota Bandung. Metode penelitian kuantitatif digunakan dengan penyebaran kuesioner kepada 226 pemuda-pemudi usia 18-29 tahun dan belum menikah di delapan gereja Injili di Kota Bandung. Hasil penelitian menunjukkan adanya hubungan signifikan antara kelekatan pemuda-ibu dengan religiositas intrinsik pada pemuda. Kelekatan pemuda-ayah tidak ditemukan berhubungan dengan religiositas intrinsik, demikian juga dengan dukungan iman orang tua.
\end{abstract}

Kata-kata kunci: Kelekatan, Dukungan Iman, Religiositas Intrinsik, Pemuda

Abstract: This study aims to find answers to research questions, namely whether or not there is a relationship between parental attachment and faith support with intrinsic religiosity of emerging adults from evangelical churches in Bandung. The research method used is quantitative by distributing questionnaires to 226 youth aged 18-29 years and not married in 8 evangelical churches in Bandung. The results showed a significant relationship between youth-mother attachment with intrinsic religiosity of youth. Youth-father attachment was not found to be related to intrinsic religiosity, nor was parental support of faith.

Keywords: Parental Attachment, Faith Support, Intrinsic Religiosity, Youth 


\section{PENDAHULUAN}

Dalam perkembangan hidupnya, individu akan melewati masa transisi dari remaja menuju dewasa. Pada masa tersebut individu tidak lagi seperti remaja, tetapi juga belum menjadi dewasa sepenuhnya. ${ }^{1}$ Pada masa ini, individu tidak lagi memiliki kebebasan seperti pada masa remaja. Individu mengalami banyak perubahan, bahkan menghadapi berbagai pilihan dalam hidup sekaligus mendapatkan kesempatan terbesar untuk mengeksplorasi berbagai kemungkinan sebelum menentukan komitmen bagi diri dan masa depannya. ${ }^{2}$ Melalui analisis teori psikologi perkembangan, masa transisi ini dialami individu yang berusia 18-20 tahun (usia pertengahan-akhir) yang disebut sebagai emerging adult. $^{3}$ Pada penelitian ini, istilah pemuda yang digunakan mengacu kepada emerging adult atau individu yang berada pada tahap perkembangan emerging adulthood.

Dalam usia yang beranjak dewasa ini, pemuda mengalami pertumbuhan dalam iman dan relasinya dengan Tuhan hingga mencapai tahap sadar untuk membuat komitmen dan bertanggung jawab atas keyakinan religius yang dianutnya. ${ }^{4}$ Mereka juga diharapkan telah mandiri dalam menetapkan identitas dan sudut pandangnya dalam hal iman, serta menilai secara kritis dan lebih objektif nilai-nilai serta keyakinan religius yang dianutnya. ${ }^{5}$ Hal serupa dinyatakan oleh Jeffrey J. Arnett bahwa masa pemuda merupakan masa pembentukan keyakinan religius, masa yang penting bagi

\footnotetext{
${ }^{1}$ Jeffrey Jensen Arnett, "Emerging Adulthood: Understanding The New Way of Coming of Age," dalam Emerging Adults in America Coming of Age in The 21st Century, ed. Jeffrey Jensen Arnett dan Jennifer Lynn Tanner (Washington: American Psychological Association, 2006), 11-12, Adobe PDF ebook.
}

${ }^{2}$ Ibid., 7.

${ }^{3}$ Jeffrey Jensen Arnett, Emerging Adulthood: The Winding Road from The Late Teens Through The Twenties (New York: Oxford University Press, 2004), 3-4, Adobe PDF ebook.

${ }^{4}$ James W. Fowler, Stages of Faith: The Psychology of Human Development and The Quest for Meaning, ed. ke-1 (San Francisco: Harper \& Row, 1981), 182.

${ }^{5}$ Ibid. perkembangan wawasan dunia yang menjadikan keyakinan dan nilai-nilai religius sebagai bagian dari wawasan dunia pemuda. ${ }^{6}$

Individu pada usia pemuda ini diharapkan mengalami perkembangan yang lebih matang dalam aspek kehidupan iman dan religiusnya jika dibandingkan saat mereka masih remaja. Namun pada kenyataannya, fenomena yang ada justru menunjukkan sebaliknya. Banyak pemuda mengalami penurunan dalam religiositasnya ketika memasuki masa transisi menuju dewasa, yang dapat dilihat melalui jumlah kehadiran pemuda di gereja sebagai salah satu indikatornya.

Banyak pemuda Kristen meninggalkan iman mereka setelah beralih dari masa remaja dan memasuki masa dewasa awal. David Kinnaman mengutip hasil penelitian Barna Group yang menunjukkan bahwa penurunan kehadiran di gereja dan partisipasi dalam kegiatan kerohanian paling banyak terjadi pada jemaat muda berusia 18-29 tahun (hasil studi nasional di Amerika tahun 1997-2010). Penurunan sebanyak $43 \%$ terjadi pada rentang usia remaja sampai dewasa awal ditemukan pada 18 juta pemuda berusia 20 tahun-an yang sebelumnya aktif mengikuti kegiatan di gereja pada waktu remaja. Ketika menginjak usia 30 tahun, mereka tidak lagi aktif di gereja. ${ }^{7}$ Menurut Kinnaman, hal ini disebabkan keterhubungan remaja dengan kekristenan tidak mendalam dan hanya sekadar identifikasi budaya saja. Dengan demikian, pada masa peralihan menuju dewasa, banyak dari mereka yang tidak lagi terlibat dengan kekristenan. ${ }^{8}$

Selanjutnya, hasil penelitian Barna pada tahun 2011 menunjukkan bahwa terdapat 59\% anak muda Kristen yang berhenti datang ke gereja pada usia peralihan menuju dewasa. Sebagian besar $(57 \%)$ pemuda mengatakan tidak lagi aktif di gereja dibandingkan saat remaja, 38\% mengaku pernah meragukan iman Kristen mereka, dan $32 \%$ mengaku bahwa

${ }^{6}$ Arnett, Emerging Adulthood, 165-166.

${ }^{7}$ David Kinnaman, You Lost Me, terj. Denny Pranolo (Bandung: Visi, 2012), 22.

${ }^{8}$ Ibid., 23. 
mereka menolak iman Kristen yang dianut orang tua mereka. ${ }^{9}$ Hasil penelitian tersebut menunjukkan adanya penurunan religiositas yang banyak terjadi pada generasi muda saat ini, khususnya di kalangan pemuda.

Dibandingkan dengan negara maju seperti Amerika Serikat, penelitian mengenai religiositas pemuda di Indonesia sendiri masih belum banyak dilakukan secara ilmiah dan terpublikasi. Pada tahun 2017, Bilangan Research Center melakukan penelitian mengenai religiositas pada remaja di Indonesia. Hasil penelitian menunjukkan bahwa religiositas pada remaja dengan mayoritas usia 15-18 tahun cukup tinggi $(63,8 \%)$, yang terlihat dari kehadiran dalam ibadah di gereja. ${ }^{10}$ Namun demikian, penelitian terhadap pemuda yang berusia 18-29 tahun belum ditemukan.

Untuk mendapatkan gambaran mengenai religiositas pemuda Kristen di Indonesia, penulis melakukan survei kepada pembina komisi pemuda di tiga gereja Injili di Kota Bandung. Salah satu indikator untuk mendapat gambaran religiositas secara umum yaitu dengan mengetahui kehadiran pemuda di gereja. Dari tiga gereja tersebut diketahui bahwa rata-rata kehadiran jemaat pemuda tidak mengalami penambahan dari tahun ke tahun.

Gereja A melaporkan rata-rata kehadiran pemuda dalam ibadah selama tiga tahun terakhir 85 orang. Jumlah pemuda yang terdaftar 120 orang, namun tidak semuanya hadir dalam ibadah. Mereka juga menyatakan tidak ada peningkatan signifikan baik dari jumlah pemuda yang terdaftar maupun dari jumlah jemaat komisi remaja yang seharusnya naik ke komisi pemuda.

Komisi pemuda di gereja B sempat ditiadakan selama 4 tahun sebab jumlah kehadiran yang menurun, sedangkan jumlah kehadiran remaja adalah rata-rata $80-90$ orang. Proses perpindahan komisi (dari remaja ke pemuda)

\footnotetext{
${ }^{9}$ Kinnaman, You Lost Me, 23-24.

${ }^{10}$ Hasil Temuan Survei Spiritualitas Generasi Muda Kristen di Indonesia oleh Bilangan Research Center yang dipaparkan melalui seminar pada 14 November 2017 di SAAT Ministry Center Jakarta.
}

tidak mampu menstabilkan jumlah kehadiran, justru terjadi penurunan. Komisi pemuda mulai berjalan kembali awal tahun 2018 dengan jumlah pemuda yang terkumpul kurang lebih 20 orang.

Hal serupa juga terjadi pada gereja $\mathrm{C}$ dengan jumlah pemuda yang tidak mengalami penambahan dari tahun ke tahun dengan ratarata 30 orang. Gereja $\mathrm{C}$ merasakan tidak adanya penambahan jumlah pemuda, terutama pada masa transisi dari remaja ke pemuda. Jemaat di komisi remaja yang seharusnya telah memasuki usia pemuda justru tidak lagi beribadah di komisi pemuda.

Dari pengalaman ketiga gereja tersebut di atas, terlihat adanya stagnasi pada jumlah kehadiran pemuda di gereja dari tahun ke tahun yang khususnya dirasakan ketika remaja yang menginjak usia pemuda tidak lagi hadir di gereja tersebut. Hal ini mungkin tidak terjadi jika remaja yang telah memasuki usia pemuda ini tetap bertahan di gereja. Jumlah kehadiran pemuda di gereja mungkin mengalami peningkatan, namun kenyataannya terjadi stagnasi atau terkadang justru adanya penurunan dalam segi jumlah kehadiran pemuda.

Berdasarkan penelitian yang ada dan survei di atas, peneliti melihat masih adanya kesenjangan antara harapan dan kenyataan mengenai religiositas pemuda. Pemuda yang diharapkan mengalami peningkatan dalam religiositas seiring dengan pertumbuhan imannya tidak terjadi. Jumlah kehadiran di gereja sebagai salah satu indikator religiositas menunjukkan fakta ini.

Pertumbuhan religiositas pada masa pemuda seyogyanya menghasilkan suatu komitmen religius yang bersifat intrinsik, atau yang biasa dikenal dengan religiositas intrinsik. Dalam menghidupi imannya, setiap generasi muda Kristen perlu memiliki religiositas intrinsik. Religiositas intrinsik berbicara mengenai komitmen religius yang merupakan motivasi untuk mengalami dan menghidupi iman satu agama demi kepentingan iman itu sendiri sehingga tercapainya tujuan dari agama tersebut, bukan karena adanya penguatan 
eksternal, melainkan karena agama itu sendiri. ${ }^{11}$

Bagi seorang Kristen, tingkat religiositas intrinsik yang tinggi menunjukkan komitmen yang tinggi pula dalam menghidupi keyakinan-keyakinan sesuai iman Kristen melalui perilaku religius seperti beribadah ke gereja, berdoa, membaca Alkitab atau literatur kekristenan yang timbul dari adanya motivasi untuk menghidupi iman itu sendiri. Sebaliknya, tingkat religiositas intrinsik rendah cenderung menunjukkan komitmen yang rendah pula dalam menghidupi keyakinankeyakinan sesuai iman Kristen melalui perilaku religius.

Yang menarik adalah justru komitmen religius pada diri pemuda yang berada dalam masa transisi menuju kedewasaan lebih rendah jika dibandingkan dengan masa-masa lain dalam perkembangan hidup manusia. Kebanyakan individu pada masa transisi sampai dewasa muda merupakan individu yang paling kurang religius dibandingkan dengan individu dewasa yang lebih tua. ${ }^{12}$ Smith dan Snell mengutip hasil survei nasional Amerika yang menunjukkan bahwa $31 \%$ generasi muda saat ini tidak pernah berkomitmen sungguh-sungguh hidup bagi Tuhan, sisanya sebesar $69 \%$ telah berkomitmen hidup bagi Tuhan, namun di antaranya hanya $4,9 \%$ pemuda yang berada pada usia 18-23 tahun. Mereka yang menyatakan berkomitmen pada Tuhan mayoritas berusia 14-17 tahun, yaitu sebanyak 58,8\%. Hasil survei ini menunjukkan bahwa lebih banyak kelompok usia remaja yang memiliki komitmen religius jika dibandingkan dengan kelompok usia pemuda. ${ }^{13}$

Dari hasil penelitian tersebut, ditemukan juga bahwa $85 \%$ remaja yang telah berkomitmen sejak usia 14 tahun, ternyata tetap memegang

\footnotetext{
${ }^{11}$ Richard L. Gorsuch, "Toward Motivational Theories of Intrinsic Religious Commitment," Journal for the Scientific Study of Religion 33, no. 4 (Desember 1994): 317, https://doi. org/10.2307/1386491.

${ }^{12}$ Christian Smith dan Patricia Snell, Souls in Transition:The Religious and Spiritual Lives of Emerging Adults (New York: Oxford University Press, 2009), 102.

${ }^{13}$ Ibid., 246.
}

komitmen mereka pada saat berusia 18-23 tahun. ${ }^{14}$ Hal ini menunjukkan bahwa kebanyakan individu yang memiliki komitmen religius sejak awal hidupnya sampai masa remaja, akan berlanjut dengan komitmen religius yang konsisten sampai pada usia transisi menuju masa dewasa. Sedangkan mereka yang memiliki komitmen religius rendah pada awal kehidupannya, hanya sedikit saja yang menunjukkan komitmen religius yang lebih tinggi saat pemuda. ${ }^{15}$ Salah satu penjelasan tentang fakta ini adalah mereka yang memiliki komitmen religius sejak usia lebih muda memiliki orang tua yang religius pula dan secara reguler hadir dalam ibadah Sekolah Minggu. Hal ini menunjukkan bahwa orang tua menjadi faktor yang signifikan bagi kehidupan religius anak-anaknya. ${ }^{16}$

Relasi orang tua dan anak dapat dijelaskan melalui konsep kelekatan yang terbentuk sejak bayi baru lahir. Orang tua, atau ibu bagi bayi merupakan figur kelekatan pertama bagi individu. Kelekatan dapat diamati pada perilaku individu yang berusaha mencari dan mempertahankan kedekatan dengan individu lain yang diharapkan sebagai figur kelekatan. ${ }^{17}$ Pada penelitian ini, kelekatan yang dimaksud adalah kelekatan pemuda dengan ayah dan ibu dan mengacu kepada persepsi pemuda mengenai kelekatan dirinya dengan ayah dan ibunya. Individu dapat dikatakan memiliki kelekatan aman jika ia memiliki rasa percaya kepada figur kelekatan yang memahami, menghargai kebutuhan dan keinginannya, serta peka dan bersedia memberikan pertolongan di saat ia membutuhkan. ${ }^{18}$ Sebaliknya, individu yang tidak lekat atau tidak aman cenderung menunjukkan adanya kemarahan atau keterpisahan emosional

\footnotetext{
${ }^{14}$ Smith dan Snell, Souls in Transition, 247.

${ }^{15}$ Ibid.

${ }^{16}$ Ibid., 254.

${ }^{17}$ John Bowlby, Attachment and Loss, ed. ke-2 (New York: Basic, 1982), 371.
} 432 
dengan figur kelekatan karena adanya rasa tidak aman di dalam diri. ${ }^{19}$

Pada masa pemuda, umumnya individu mulai membangun kelekatan dengan pasangan dan mulai memiliki otonomi. Meskipun demikian, hal tersebut tidak berarti bahwa kelekatan dengan orang tua berhenti atau hilang. Sebaliknya kebanyakan individu dewasa melanjutkan hubungan yang bermakna dengan orang tua sekalipun orang tua tidak banyak memberi intervensi lagi dalam kehidupan mereka. ${ }^{20}$

Penelitian terhadap 100 mahasiswa tingkat pertama di Amerika menyebutkan bahwa kelekatan dengan orang tua, khususnya ibu, berhubungan dengan tingkat komitmen dan eksplorasi identitas yang tinggi. ${ }^{21}$ Selain itu, sejak memasuki usia kuliah, pada umumnya pemuda merasa hubungannya dengan orang tua justru meningkat, lebih menguntungkan, dan lebih sehat. ${ }^{22}$ Penelitian mengenai kelekatan dengan orang tua dan religiositas pada remaja menyebutkan bahwa kelekatan dengan tingkat rasa aman tinggi cenderung membuat remaja mengadopsi keyakinan agama yang disosialisasikan orang tuanya. ${ }^{23}$ Apabila kelekatan yang kuat dengan orang tua ini terus berlanjut sampai pada masa pemuda, maka ada kemungkinan pembagian keyakinan agama oleh orang tua terus berlanjut, sebab mereka tetap merupakan figur

\footnotetext{
${ }^{19}$ Armsden dan Greenberg, "The Inventory of Parent," 432.

${ }^{20}$ Mary D. Ainsworth, "Attachments Beyond Infancy," The American Psychologist 44, no. 4 (April 1989): 709-716, http://dx.doi.org/10.1037/0003-066X.44.4.709.

${ }^{21}$ Jessica Samuolis, Kiera Layburn, dan Kathleen M. Schiaffino, "Identity Development and Attachment to Parents in College Students," Journal of Youth and Adolescence 30, no. 3 (1 Juni, 2001): 381-382, https://doi. org/10.1023/A:1010448313516.
}

${ }^{22}$ Eva S. Lefkowitz, “'Things Have Gotten Better': Developmental Changes Among Emerging Adults After the Transition to University," Journal of Adolescent Research 20, no. 1 (Januari 2005): 42, https://doi.org/10.1177/0743558404271236.

${ }^{23} \mathrm{Pehr}$ Granqvist, “Attachment and Religiosity in Adolescence: Cross-Sectional and Longitudinal Evaluations," Personality and Social Psychology Bulletin 28, no. 2 (1 Februari 2002): 266, https://doi.org/10.1177/0146167202282011. kelekatan yang penting bagi pemuda dalam masa-masa peralihan ini. ${ }^{24}$ Dengan demikian, jika melihat bahwa relasi dengan orang tua tetap memberikan dasar rasa aman bagi pemuda, khususnya dalam pembagian keyakinan agama, maka ada kemungkinan terdapat hubungan antara kelekatan dengan orang tua dan religiositas (intrinsik).

Selain kelekatan, dukungan iman juga berkontribusi bagi perkembangan iman individu. Kelly D. Schwartz menyatakan bahwa hal ini terjadi dengan transmisi melalui pemodelan iman maupun transaksi melalui dialog iman. ${ }^{25}$ Dukungan iman merupakan bentuk dukungan yang diterima individu dalam proses perkembangan iman religiusnya, dan dapat berasal dari orang tua, teman, sekolah, maupun komunitas gereja.

Dukungan iman orang tua dinyatakan berhubungan dengan religiositas intrinsik pemuda. ${ }^{26}$ Sosialisasi agama melalui orang tua masih menjadi salah satu faktor penting yang berdampak pada religiositas pemuda, khususnya sosialisasi dari orang tua yang religius. ${ }^{27}$ Baik tinggi atau rendahnya dukungan iman yang diterima pemuda dari orang tua tampaknya berdampak terhadap religiositas mereka. Di Indonesia, penelitian tentang religiositas untuk kalangan emerging adult belum ditemukan.

Berdasarkan pemaparan di atas, penulis tertarik untuk melakukan penelitian terhadap religiositas intrinsik, kelekatan pemuda-orang tua, dan dukungan iman orang tua. Dengan

\footnotetext{
${ }^{24}$ Miri Scharf, Ofra Mayseless, dan Inbal Kivenson-Baron, “Adolescents' Attachment Representations and Developmental Tasks in Emerging Adulthood," Developmental Psychology 40, no. 3 (2004): 439, https://doi. org/10.1037/0012-1649.40.3.430

${ }^{25}$ Kelly D. Schwartz, "RESEARCH: Transformations in Parent and Friend Faith Support Predicting Adolescents' Religious Faith," International Journal for the Psychology of Religion 16, no. 4 (Oktober 2006): 311-326, https://doi. org/10.1207/s15327582ijpr1604_5

${ }^{26}$ Kathleen C. Leonard et al., "Parent-Child Dynamics and Emerging Adult Religiosity: Attachment, Parental Beliefs, and Faith Support.," Psychology of Religion and Spirituality 5, no. 1 (2013): 9, https://doi.org/10.1037/a0029404
}

${ }^{27}$ Smith dan Snell, Souls in Transition, 285. 
demikian, penelitian ini ditujukan untuk menjawab hipotesis: (1) Terdapat hubungan antara kelekatan pemuda-orang tua (ayah dan ibu) dengan religiositas intrinsik pada pemuda, dan (2) Terdapat hubungan antara dukungan iman orang tua (ayah dan ibu) dengan religiositas intrinsik pada pemuda.

\section{TELAAH LITERATUR}

\section{Religiositas Intrinsik}

Dalam perspektif psikologi agama, religiositas merupakan suatu konsep yang menjelaskan tentang ketaatan seseorang terhadap keyakinan dan praktik yang dilakukan dalam suatu institusi agama atau organisasi gereja. ${ }^{28}$ Berbagai penelitian telah dilakukan berkenaan dengan perilaku religius individu. Salah satu konsep yang telah banyak digunakan dalam berbagai penelitian religiositas yaitu konsep tentang orientasi religius intrinsik/ekstrinsik, yang diukur melalui Allport's Religious Orientation Scale (ROS). ${ }^{29}$ Dalam tesis ini, peneliti berfokus kepada pengukuran religiositas intrinsik melalui alat ukur $I / E$ Revised Scale-bentuk modifikasi dari alat ukur ROS—sementara faktor ekstrinsik tidak diukur.

Konsep religiositas intrinsik bermula dari istilah orientasi religius yang digunakan Allport dalam penelitiannya pada tahun 1963 mengenai ilmu perilaku, agama, dan kesehatan mental. ${ }^{30}$ Allport menyebutkan bahwa terdapat dua bentuk agama, yaitu agama intrinsik dan agama ekstrinsik. Agama intrinsik bermakna sebagai sesuatu yang dihidupi, sementara agama ekstrinsik bermakna sebagai sesuatu yang

${ }^{28}$ Edward P. Shafranske, "Clinical Psychologists' Religious and Spiritual Orientations and Their Practice of Psychotherapy," dalam Psychology of Religion: Personalities, Problems, Possibilities, ed. H. Newton Malony (Grand Rapids: Baker, 1991), 550.

${ }^{29}$ Michael J. Donahue, "Intrinsic and Extrinsic Religiousness: Review and Meta-Analysis," Journal of Personality and Social Psychology 48, no. 2 (1985): 400, https://doi. org/10.1037/0022-3514.48.2.400.

${ }^{30}$ Gordon W. Allport, "Behavioral Science, Religion, and Mental Health," Journal of Religion and Health 2, no. 3 (1963): 193, https://doi.org/10.1007/BF01533333. dipergunakan, misalnya untuk meningkatkan status seseorang, rasa percaya diri, penghasilan, mendapat teman, kekuasaan, atau pengaruh, dan yang terutama sebagai dukungan utama bagi kehidupan pribadi. ${ }^{31}$

Religiositas intrinsik berbicara mengenai komitmen religius yang didefinisikan sebagai "the motivation for experiencing and living one's religious faith for the sake of the faith itself. The person's religion is an end unto itself, a goal pursued in the absence of external reinforcement." 32 Religiositas intrinsik disebut sebagai komitmen religius yang didorong oleh motivasi seseorang untuk mengalami dan menghidupi iman agamanya. Motivasi tersebut timbul dari dirinya sendiri, untuk mengejar iman itu sendiri, bukan untuk mengejar hal eksternal yang dapat menyertainya. Dengan demikian, perilaku dan keyakinan iman individu dengan religiositas intrinsik tidak didasarkan pada ada atau tidaknya penguat eksternal yang dapat meningkatkan perilaku dan keyakinan religiusnya.

Terdapat dua komponen dalam motivasi intrinsik seseorang. Pertama, afeksi, yaitu perasaan suka atau tidak suka kepada praktik religius yang dilakukan. ${ }^{33}$ Dalam jiwa manusia terdapat pemikiran dan afeksi atau perasaan. Dengan pemikiran yang dimiliki, individu mampu memersepsi dan berspekulasi tentang berbagai hal sehingga dapat memberikan penilaian, termasuk juga persepsi terhadap hal-hal religius. ${ }^{34}$ Bagian afeksi manusia dimengerti sebagai kecenderungan atau kehendak hati manusia yang dipandang sebagai bagian terbesar dari agama yang sejati, sebab afeksi menunjukkan bahwa agama itu benar dan suci dalam kemuliaannya yang khusus. ${ }^{35}$ Kedua, nilai moral, yaitu persepsi pribadi seseorang tentang kewajiban moral. Nilai

\footnotetext{
${ }^{31}$ Ibid.

${ }^{32}$ Gorsuch, "Toward Motivational Theories," 317.

${ }^{33}$ Ibid.

${ }^{34}$ Jonathan Edwards, Religious Affections: A Christian's Character Before God, ed. J.M. Houston (Vancouver: Regent College, 2003), 5-6.

${ }^{35} \mathrm{Ibid}$.
} 
moral diperlukan bagi kepentingan pribadi dan berlaku universal dalam situasi apa pun. ${ }^{36}$ Dengan demikian, perasaan terhadap agama atau hal-hal religius dan persepsi terhadap nilai moral menjadi bagian dari motivasi intrinsik individu.

Religiositas intrinsik juga terbentuk melalui proses yang dapat dijelaskan melalui empat hal. Pertama, familiaritas. Seseorang memiliki komitmen religiositas yang intrinsik karena adanya pengalaman yang akrab dengan halhal religius, khususnya yang dirasakan akrab secara afek atau perasaan. ${ }^{37}$ Individu yang telah terbiasa melakukan kegiatan religius dengan keyakinan agama tertentu merasa akrab dengan hal tersebut sehingga lambat laun terbentuk religiositas intrinsik. Kedua, aspek kognitif. Proses kognitif dapat dijelaskan melalui teori kognitif. Sistem berpikir manusia cenderung menuntut konsistensi dan pemikiran yang logis sehingga dorongan untuk memunculkan perilaku religius cenderung akan didasari oleh pemikiran yang konsisten dengan perilaku tersebut. ${ }^{38}$ Ketiga, kebutuhan terhadap agama itu sendiri. Individu memiliki kebutuhan dasar untuk menjadi religius yang perlu untuk dipenuhi. Melalui kebutuhan tersebut, individu terdorong secara intrinsik untuk memunculkan perilaku dan keyakinan religius sesuai dengan agama yang dianutnya. ${ }^{39}$ Kebutuhan ini dapat terpenuhi antara lain melalui berbagai perilaku religius, misalnya beribadah, berdoa, dan membaca Kitab Suci. ${ }^{40}$ Keempat, motivasi intrinsik, yang terbentuk karena adanya determinasi diri yang memampukan individu memilih melakukan aktivitas tertentu secara sukarela dan tanpa paksaan dari luar diri. Individu yang memiliki motivasi intrinsik terhadap agamanya akan berkomitmen pada kepercayaan agamanya itu karena tertarik atau berminat terhadap keyakinan atau perilaku religiusnya, bukan

\footnotetext{
${ }^{36}$ Edwards, Religious Affections, 5-6.

${ }^{37}$ Gorsuch, "Toward Motivational Theories," 320.

${ }^{38}$ Ibid., 320-321.

${ }^{39}$ Ibid., 321.

${ }^{40}$ Ibid., 322.
}

karena ingin mendapatkan sukacita dan kepuasan pribadi melalui agamanya. ${ }^{41}$

Selain itu, terdapat lima faktor yang berdampak terhadap komitmen dan praktik religius pada pemuda. Faktor-faktor ini dialami ketika usia remaja, yang kemudian setelah melalui pengukuran diketahui membawa dampak pada tingginya religiositas selama usia pemuda. ${ }^{42}$ Pertama, teladan dan dukungan relasional yang kuat terhadap komitmen religius dari orang tua selama usia remaja. ${ }^{43} \mathrm{Kedua}$, kehadiran orang dewasa selain orang tua dalam gereja yang dengannya remaja dapat memperoleh dukungan, nasihat, dan pertolongan. ${ }^{44}$ Ketiga, frekuensi dalam mempraktikkan saat teduh pribadi melalui doa dan pembacaan Alkitab. Berdoa dan membaca Alkitab pada umumnya dapat meningkatkan relasi orang percaya dengan Allah, meneguhkan iman, dan menambah pengenalan akan Allah, serta keyakinan agama seseorang. ${ }^{45}$ Keempat, penilaian yang tinggi terhadap pentingnya iman. Individu yang sejak remaja telah memandang iman sebagai hal yang sangat penting dalam hidupnya cenderung akan tetap memegang komitmen religiusnya selama masa pemuda. ${ }^{46}$ Kelima, banyaknya pengalaman religius. Pengalaman religius dapat meningkatkan kerinduan dan komitmen religius terhadap keyakinan yang diterima secara kognitif serta meningkatkan pemahaman dan praktik iman. ${ }^{47}$

\section{Kelekatan}

Kelekatan adalah ikatan afeksional yang bertahan dan memiliki intensitas tinggi. ${ }^{48}$ Oleh sebab itu, ikatan kelekatan hanya ditemukan

${ }^{41}$ Ibid.

${ }^{42}$ Smith dan Snell, Souls in Transition, 217.

${ }^{43}$ Ibid., 231.

${ }^{44}$ Ibid., 233-234.

${ }^{45}$ Ibid., 234-235.

${ }^{46}$ Ibid., 236-237.

${ }^{47}$ Ibid., 238.

${ }^{48}$ Armsden dan Greenberg, "The Inventory of Parent," 428. 
pada relasi yang dipersepsi mengandung muatan emosional yang signifikan. ${ }^{49}$ Individu yang memiliki kelekatan terhadap figur signifikan dalam hidupnya akan mengalami rasa aman yang menjadikan kelekatan tersebut bertahan. Rasa aman ini juga akan membuatnya mampu mengatasi ketakutan ketika figur kelekatan tidak hadir pada saat ia membutuhkannya, dan memampukannya menyesuaikan diri dengan baik. ${ }^{50}$ Menurut Ainsworth kelekatan yang terjadi antara anak dengan orang tua memampukan anak untuk bersikap toleran terhadap perpisahan dengan orang tua, misalnya ibu, untuk periode waktu tertentu dengan tingkat stres yang rendah. ${ }^{51}$ Oleh karena itu, persepsi individu terhadap kelekatan merupakan hal yang penting, apakah ia merasa aman dan nyaman atau sebaliknya, merasa terancam. Rasa aman menjadi hal yang sangat signifikan untuk menentukan adanya kelekatan sebab dengan adanya rasa aman, individu dapat menaruh kepercayaan kepada figur kelekatan. ${ }^{52}$

Dengan adanya kelekatan yang aman sejak bayi, secara perlahan individu belajar membangun rasa percaya dan rasa amannya hingga pada akhirnya dia berani keluar dari rasa amannya untuk mengeksplorasi dunia luar dengan berbagai hubungan yang lebih luas seperti dengan teman dan bahkan dengan orang asing. ${ }^{53}$ Ainsworth juga menjelaskan bahwa ikatan emosi yang tampak dari perilaku kelekatan itu berbeda dengan relasi pada umumnya, sebab ikatan emosi relatif bertahan lama dengan adanya usaha individu untuk mempertahankan kedekatan dengan figur kelekatan, sedangkan dalam relasi, ikatan emosi belum tentu bertahan lama. ${ }^{54}$

\footnotetext{
${ }^{49}$ Armsden dan Greenberg, "The Inventory of Parent,"

${ }^{50}$ Ibid., 428.

${ }^{51}$ Ainsworth, “Attachments Beyond Infancy,” 710.

${ }^{52}$ Armsden dan Greenberg, "The Inventory of Parent,"

${ }^{53}$ Ibid.

${ }^{54}$ Ibid., 711.
} 429. 442.
Kelekatan dengan ayah dan ibu dapat dipahami melalui tiga komponen. Pertama, kepercayaan. Kepercayaan dapat terbentuk ketika individu merasa bahwa ayah dan ibu memahami dan menghargai keberadaan dirinya dengan segala kebutuhan dan keinginannya. Kepercayaan ini juga berarti bahwa individu memandang ayah dan ibu peka serta responsif terhadap keadaan emosi mereka, dan bersedia menunjukkan kepedulian dengan membantu. Dengan adanya rasa percaya, maka individu dapat membangun hubungan dengan kualitas kelekatan yang aman. ${ }^{55}$ Kedua, komunikasi. Komunikasi merupakan salah satu komponen yang dapat menjelaskan seseorang merasa aman atau tidak. Seseorang yang merasa cemas atau takut cenderung sulit berkomunikasi sebagaimana seharusnya, dan hal ini akan muncul ketika berhadapan dengan figur yang tidak memberikan rasa aman. ${ }^{56}$ Ketiga, keterasingan. Keterasingan merupakan komponen yang dinilai secara terbalik karena mengandung aspek perilaku, kognitif, dan afektif yang lebih negatif dibandingkan dengan dua komponen sebelumnya. Keterasingan dapat dijelaskan sebagai perasaan marah atau emosi yang tidak lekat dengan ayah atau ibu, yang memberikan kelekatan tidak aman pada individu. ${ }^{57}$ Dengan melihat ketiga komponen di atas, maka dapat diketahui bagaimana persepsi individu mengenai kelekatannya dengan orang tua, apakah aman atau tidak aman.

Individu yang memiliki dasar kelekatan aman dengan orang tuanya akan menjadi diri yang aman yang memiliki kualitas kekuatan emosional yang tampak dari kemampuannya menerima berbagai emosi positif maupun negatif. Dia juga tidak memandang emosi negatif sebagai tanda kelemahan atau ketidakseimbangan. ${ }^{58}$ Selain itu, individu yang aman lebih memiliki kemauan untuk mencari dan

\footnotetext{
${ }^{55}$ Ibid., 432.

${ }^{56}$ Richard H. Klemer, Marriage and Family Relationships (New York: Harper \& Row, 1970), 207-208.

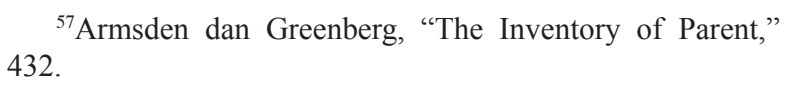
432.

${ }^{58}$ Timothy E. Clinton dan Gary Sibcy, Attachments: Why You Love, Feel, and Act The Way You Do: Unlock The Secret 
menerima kenyamanan, khususnya pada saat menghadapi kesulitan. Dengan demikian, individu yang merasa aman juga cenderung mudah mencari Tuhan dalam doa. ${ }^{59}$ Selain itu, individu juga meyakini bahwa ada keamanan pada orang lain sehingga membuatnya percaya dan mencari pertolongan dari orang lain pula. Oleh karena itu, individu juga lebih berani untuk mengasihi dan memiliki keintiman dengan orang lain. ${ }^{60}$ Individu yang memiliki rasa aman juga dapat bertanggung jawab atas tindakannya sendiri serta memiliki keberanian. ${ }^{61}$ Rasa aman membuat seseorang percaya bahwa dirinya dikasihi sehingga sekalipun ayah atau ibunya tidak hadir, dia tidak khawatir atau berpikir bahwa dirinya dilupakan dan akan ditinggalkan. ${ }^{62}$

Sebaliknya, individu yang memiliki kelekatan dengan tingkat rasa aman rendah akan memiliki tingkat kepercayaan dan komunikasi yang rendah; dan keterasingan yang sedang atau tinggi. Selain itu, jika salah satu dari tingkat kepercayaan atau komunikasi sedang dan yang lain rendah, maka akan disertai tingkat keterasingan yang tinggi. ${ }^{63}$ Pola kelekatan tidak aman muncul dari pengalaman ditinggalkan oleh figur kelekatan sehingga individu tidak dapat bergantung dan percaya kepada figur tersebut. Garland menegaskan, baik orang dewasa maupun anak-anak dapat mengalami kelekatan tidak aman. ${ }^{64}$

Seiring dengan perjalanan hidupnya, kelekatan yang terjadi antara individu dengan orang tua turut mengalami perkembangan. Ketika individu mulai remaja dan bertambah dewasa, terjadi perubahan perilaku kelekatan

to Loving and Lasting Relationships (Brentwood: Integrity, 2002), 139.

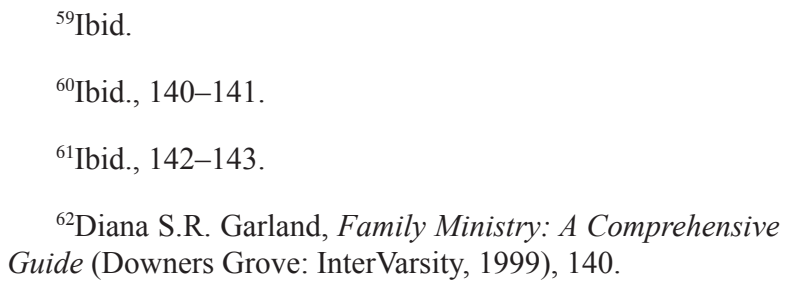

${ }^{63}$ Armsden dan Greenberg, "The Inventory of Parent,"

${ }^{64}$ Garland, Family Ministry, 140. yang ditujukan kepada figur kelekatan selain ibu. ${ }^{65}$ Pada waktu remaja, perilaku kelekatan sering kali tidak ditujukan kepada orang tua saja, melainkan juga kepada teman sebaya. ${ }^{66}$ Orang yang lebih dewasa, mentor, pendeta, terapis atau konselor juga dapat menjadi figur kelekatan bagi mereka, selama figur tersebut menginspirasi dasar kepercayaannya dan menyediakan rasa aman baginya ${ }^{67}$ Mulai usia pemuda bahkan sampai dewasa individu memiliki figur kelekatan jamak, tidak hanya satu dan tidak terbatas hanya pada pasangan seksual, tetapi juga termasuk orang tua, pasangan, dan teman-teman. ${ }^{68}$

Secara khusus bagi pemuda, sekalipun mereka mulai memiliki otonomi terpisah dari orang tua dan menjalin hubungan romantis, kelekatan dengan orang tua yang telah terbangun sejak bayi tetap ada, bahkan kebanyakan dari mereka melanjutkan hubungan yang bermakna dengan orang tuanya. ${ }^{69}$ Walaupun hidup terpisah, pemuda akan berupaya mencari kedekatan yang dilakukan dalam bentuk berbeda, misalnya dalam cara berkomunikasi dan cara pendekatan melalui telepon. ${ }^{70}$ Kerinduan kepada orang tua tetap ada, meskipun pemuda mampu mengatasi perpisahan tersebut. Kelekatan akan mendorong individu untuk terus mempertahankan kedekatan yang dibutuhkan. ${ }^{71}$ Ikatan dengan figur kelekatan ini terus menetap dan berdampak pada cara individu tersebut berelasi dengan orang lain. ${ }^{72}$

\footnotetext{
${ }^{65}$ Bowlby, Attachment and Loss, 179.

${ }^{66}$ Armsden dan Greenberg, "The Inventory of Parent,"

${ }^{67}$ Ainsworth, “Attachments Beyond Infancy,” 711.

${ }^{68}$ Shanna J. Trinke dan Kim Bartholomew, "Hierarchies of Attachment Relationships in Young Adulthood," Journal of Social and Personal Relationships 14, no. 5 (1 Oktober 1997): 604, 607, https://doi.org/10.1177/0265407597145002.

${ }^{69}$ Ainsworth, “Attachments Beyond Infancy,” 710.

${ }^{70}$ Mary I. Campa, Cindy Hazan, dan Jared E. Wolfe, "The Form and Function of Attachment Behavior in The Daily Lives of Young Adults," Social Development 18, no. 2 (Mei 2009): 290, https://doi.org/10.1111/j.1467-9507.2008.00466.x.
} 429. 428

${ }^{71}$ Armsden dan Greenberg, "The Inventory of Parent,"

${ }^{72}$ Ibid. 
Kehilangan figur kelekatan dapat membawa perasaan sengsara atau berduka bagi individu yang mengalaminya. ${ }^{73}$

\section{Dukungan Iman Orang Tua}

Teori dukungan iman tidak terlepas dari adanya proses transmisi nilai dan keyakinan religius yang diteruskan oleh agen sosialisasi. Berdasarkan perannya, orang tua merupakan agen sosialisasi yang utama bagi anak. ${ }^{74}$ Proses transmisi nilai dan keyakinan religius dari orang tua merupakan bentuk sosialisasi yang disertai dengan internalisasi pada individu. ${ }^{75}$ Proses internalisasi nilai dan keyakinan ini terjadi di antara kedua pihak, baik indivi$\mathrm{du}$ maupun orang tua yang berperan secara aktif. ${ }^{76}$ Secara umum, internalisasi merupakan proses yang melaluinya individu menerima hal-hal yang disosialisasikan oleh agen sosial lain-bisa pribadi, institusi, atau konstruk budaya — ke dalam proses pemikiran dan perasaan intrapsikis individu. ${ }^{77}$

Dukungan iman yang diukur dalam penelitian ini mengacu kepada konsep dukungan iman yang telah diteliti sebelumnya oleh Kelly Dean Schwartz dan berfokus kepada keunikan dan peran komplementer dari orang tua dan teman sebaya. ${ }^{78}$ Dukungan iman merupakan bentuk dukungan yang diterima individu dalam proses perkembangan iman religiusnya, baik berupa transmisi melalui pemodelan iman maupun transaksi melalui dialog iman. ${ }^{79}$ 711.

${ }^{73}$ Armsden dan Greenberg, "The Inventory of Parent,"

\footnotetext{
${ }^{74}$ Douglas L. Flor dan Nancy Flanagan Knapp, “Transmission and Transaction: Predicting Adolescents' Internalization of Parental Religious Values.," Journal of Family Psychology 15, no. 4 (2001): 627, https://doi. org/10.1037/0893-3200.15.4.627.

${ }^{75}$ Ibid., 629.

${ }^{76}$ Ibid.

${ }^{77}$ Jeanette A. Lawrence dan Joan Valsiner, "Conceptual Roots of Internalization: From Transmission to Transformation," Human Development 36, no. 3 (1993): 151, https://doi. org/10.1159/000277333.
}

\footnotetext{
${ }^{78}$ Schwartz, "RESEARCH," 324.

${ }^{79}$ Schwartz, ., 314.
}

Dukungan iman datang dari lingkungan sosial yang mendukung individu. Dukungan iman yang pertama kali didapatkan adalah dari keluarga yang telah terlebih dahulu menganut agama tertentu. Keluarga disebutkan sebagai mekanisme terpenting dalam transmisi nilai antargenerasi..$^{80}$ Melalui keluarga juga, orang tua meneruskan keyakinan dan praktik religius kepada anak-anaknya sehingga keberlangsungan komunitas dan tradisi agama yang dianut keluarga dapat terus bertahan dan terpelihara. ${ }^{81}$ Di samping itu, pengajaran dan pemodelan religius dalam keluarga menjadi perangkat utama bagi perkembangan iman dan kerohanian anggota keluarga. Dalam keluarga Kristen, pendidikan agama dan iman Kristen menjadi fokus perhatian utama sekaligus panggilan ilahi yang diberikan Allah kepada orang tua untuk meneruskannya kepada anak-anak mereka. ${ }^{82} \mathrm{Hal}$ ini menunjukkan bahwa dukungan iman merupakan hal yang sangat penting bagi perkembangan iman seseorang, khususnya dalam kekristenan. ${ }^{83}$ Pembentukan iman ini diupayakan terutama di dalam keluarga dan bekerja sama dengan gereja. ${ }^{84}$

Dukungan iman dari orang tua dapat diamati melalui bagaimana persepsi pemuda mengenai dukungan iman yang diterimanya dari orang tua, yaitu ayah dan ibu. Dukungan iman dapat berbentuk transmisi dan juga transaksi yang terjadi di antara pemuda dengan orang tuanya. Transmisi nilai, keyakinan, dan perilaku iman kepada anak dilakukan melalui

\footnotetext{
${ }^{80}$ Dean R. Hoge, Gregory H. Petrillo, dan Ella I. Smith, "Transmission of Religious and Social Values from Parents to Teenage Children," Journal of Marriage and Family 44, no. 3 (1982): 569, https://doi.org/10.2307/351580.

${ }^{81}$ Paul Vermeer, "Religion and Family Life: An Overview of Current Research and Suggestions for Future Research," Religions 5, no. 2 (14 April 2014): 402, https://doi. org/10.3390/rel5020402.

${ }^{82}$ Marcia J. Bunge, "Biblical and Theological Perspectives on Children, Parents, and 'Best Practices' for Faith Formation: Resources for Child, Youth, and Family Ministry Today," Dialog 47, no. 4 (Desember 2008): 351, http://doi. org/10.1111/j.1540-6385.2008.00414.x.

${ }^{83}$ Ibid., 349.

${ }^{84}$ Ibid., 350.
} 
pemberian teladan.$^{85}$ Melalui transmisi, orang tua secara aktif menunjukkan keterlibatannya dalam hal religius, misalnya melalui kehadiran orang tua bersama anak di gereja, melakukan pelayanan, memiliki waktu teduh dengan Tuhan melalui doa dan membaca Alkitab, serta menunjukkan sikap hidup sebagai orang Kristen sejati. ${ }^{86}$ Model transmisi ini juga sering kali dikenal dengan dukungan yang bersifat informal, yang diberikan dengan cara orang tua memberi teladan tentang kebenaran dan nilai-nilai rohani kepada anak. ${ }^{87}$ Kegiatan religius yang ditunjukkan orang tua memungkinkan anak mengamati perilaku dan nilai-nilai religius orang tuanya, kemudian menginternalisasi nilai-nilai tersebut dan mereka pun menunjukkan perilaku religius serupa. ${ }^{88}$

Perilaku religius orang tua yang diamati oleh remaja dapat menentukan nilai dan perilaku remaja tidak hanya secara eksternal, melainkan sampai menjadi bagian dari diri mereka. ${ }^{89}$ Walaupun proses transmisi ini terjadi searah dari orang tua kepada anak, hal ini tetap dinilai berdampak terhadap proses internalisasi pada remaja. Hasil utama yang tampak dari transmisi keyakinan dan praktik-praktik religius dari orang tua kepada anak dapat diamati melalui kehadiran dan aktivitas ibadah yang dilakukan anak. ${ }^{90}$ Sekalipun model dukungan transmisi ini penting dan berpengaruh, perlu disertai juga dengan model transaksi antara anak dan orang tua.

Model transaksi berupa dialog iman tidak hanya dilakukan oleh pihak orang tua, melainkan juga melibatkan tindakan dan intensi anak yang secara aktif mendiskusikan keyakinan iman yang dibagikan orang tuanya sehingga proses internalisasi iman terjadi pada

\footnotetext{
${ }^{85}$ Schwartz, "RESEARCH,” 312.

${ }^{86}$ Ibid.

${ }^{87}$ Richard Ross, Student Ministry and The Supremacy of Christ (Bloomington: Crossbooks, 2009), 149.

${ }^{88}$ Flor dan Knapp, “Transmission and Transaction," 629.

${ }^{89}$ Ibid., 641.

${ }^{90}$ Vermeer, "Religion and Family Life," 404.
}

orang tua maupun anak. ${ }^{91}$ Dukungan melalui transaksi ini berbeda dengan model dukungan transmisi yang bersifat searah. Transaksi melalui dialog yang terjadi antara orang tua dan anak terjadi secara dua arah dan bersifat timbal balik. Dialog iman dapat diamati melalui kegiatan bersama antara anak dan orang tua yang bersama-sama melakukan diskusi tentang firman Tuhan, atau membicarakan pergumulan rohani dan perihal religius lainnya. ${ }^{92}$ Dampak dari model transaksi melalui diskusi iman ini lebih besar terhadap nilai penting agama bagi anak daripada terhadap perilaku religius anak, namun kedua hal ini sama-sama penting bagi kedua pihak. ${ }^{93}$ Ketika orang tua memiliki keinginan yang besar untuk menjadikan anaknya religius, maka diskusi iman dapat berkontribusi secara signifikan terhadap perilaku religius dan nilai penting agama bagi anak. $^{94}$

Kedua model dukungan ini sama-sama memiliki dampak yang kuat terhadap internalisasi nilai, keyakinan, dan perilaku religius pada anak. Meskipun demikian, model transmisi tidak dapat menggantikan pentingnya transaksi, begitu pun sebaliknya. Keduanya sama baik dan pentingnya bagi pertumbuhan iman individu. Gabungan dari kedua model dukungan iman ini disebut sebagai model transformasi. Aplikasi model transmisi dan transaksi ini juga dinilai sebagai cara yang lebih baik dalam membentuk sudut pandang anak mengenai agama, serta mempertahankan keyakinan dan komitmen religius individu..$^{95}$

\section{Kelekatan Pemuda-Orang Tua dan Religiositas Intrinsik}

Keberadaan individu tidak dapat dilepaskan dari kehadiran orang tua dalam hidupnya. Relasi anak dengan orang tua dapat digambarkan melalui ikatan emosi yang terjadi dan

\footnotetext{
${ }^{91}$ Schwartz, "RESEARCH,” 312.

${ }^{92}$ Ross, Student Ministry, 149.

${ }^{93}$ Flor dan Knapp, "Transmission and Transaction,” 640.

${ }^{94}$ Ibid., 641.

${ }^{95}$ Schwartz, "RESEARCH,” 313.
} 
bertahan di antara anak dengan orang tua, yang disebut dengan kelekatan. Kelekatan dengan orang tua juga terkait erat dengan fungsi hidup manusia secara keseluruhan, termasuk dimensi psikologis, perilaku, kognitif, dan juga spiritual, sekalipun kelekatan bukanlah faktor satu-satunya. ${ }^{96}$ Hal ini menunjukkan bahwa hubungan yang disertai kelekatan dengan orang tua berperan penting bagi kehidupan individu, termasuk dalam hal kehidupan rohani dan agamanya.

Anak yang memiliki kelekatan aman dengan orang tuanya cenderung menghasilkan sikap antusias pada anak dalam menjalani iman Kristen. ${ }^{97}$ Mereka akan lebih mudah menerima keyakinan dan nilai-nilai yang diajarkan orang tua kepadanya (khususnya orang tua yang religius) sehingga menjadi lebih antusias menjalani iman Kristen. Selain itu, sering kali kelekatan aman dengan orang tua menghasilkan kelekatan dengan Tuhan apabila orang tua memiliki tingkat kerohanian yang tinggi. ${ }^{98}$ Hal ini dapat terjadi karena pola kelekatan yang aman antara anak dengan orang tuanya membuatnya dapat mengulang kembali pola yang sama untuk lekat dengan orang lain, bahkan juga dengan Tuhan. Anak yang memiliki pola kelekatan aman dengan orang tua yang religius menunjukkan pola yang sama dalam relasinya dengan Tuhan.

Hasil penelitian kepada 203 mahasiswa di Swedia pada tahun 1998 mengenai kelekatan dan religiositas menunjukkan bahwa terdapat dampak interaksi yang signifikan antara religiositas ibu dan kelekatan dengan ibu dalam memprediksi tingkat religiositas dan perubahan religiositas yang terjadi pada responden. Selain itu, terdapat interaksi antara religiositas ayah dan kelekatan dengan ayah yang memprediksi tingkat religiositas dan

${ }^{96}$ Seong Eun Kim, "The Relationship of Parental Attachment and Christian Spirituality with Intergenerational Conflict Between Korean-American Young Adults and Their Parents," Journal of Psychology \& Theology 41, no. 3 (September 2013): 190, https://doi.org/10.1177/009164711304100302.

${ }^{97}$ Ibid., 191.

${ }^{98}$ Ibid. hubungan dengan Tuhan pada responden. ${ }^{99}$ Berdasarkan hasil penelitian ini dapat terlihat adanya hubungan antara kualitas kelekatan pemuda-orang tua dengan tingkat religiositas apabila ayah dan ibu memiliki religiositas yang tinggi.

Pada pemuda, kelekatan dengan orang tua, khususnya ibu, memberikan rasa aman baginya untuk terbuka membahas hal-hal yang rohani dan religius dengan orang tuanya. Keterbukaan dapat terjadi ketika anak memiliki rasa percaya kepada orang tuanya yang merupakan salah satu komponen kelekatan. ${ }^{100}$ Dengan adanya kepercayaan anak kepada orang tua, pemuda cenderung akan lebih mudah menerima pandangan, keyakinan, dan nilai-nilai religius yang dibagikan orang tuanya.

\section{Dukungan Iman Orang Tua dan Religiositas Intrinsik}

Sosialisasi nilai-nilai religius tidak hanya terjadi pada anak dan remaja saja, tetapi juga pada pemuda. Setiap perilaku religius seseorang tidak dapat dilepaskan dari imannya, khususnya religiositas intrinsik yang merupakan komitmen individu untuk menghidupi imannya yang muncul dari motivasi intrinsik.

Sosialisasi religius diidentifikasi sebagai proses dinamis yang dapat meningkatkan religiositas pada anak. Hal ini dapat diamati melalui komunikasi mengenai iman yang terbuka dan timbal balik antara anak dengan orang tua yang disebutkan dapat meningkatkan iman pada remaja. ${ }^{101}$ Di samping itu, penelitian Schwartz mengenai dukungan iman orang tua yang dilakukan kepada lebih dari 7000 remaja

${ }^{99}$ Pehr Granqvist, "Religiousness and Perceived Childhood Attachment: On the Question of Compensation or Correspondence," Journal for the Scientific Study of Religion 37, no. 2 (Juni 1998): 357, https://doi.org/10.2307/1387533.

${ }^{100}$ Brelsford dan Mahoney, "Spiritual Disclosure Between Older," 63.

${ }^{101}$ David C. Dollahite dan Jennifer Y. Thatcher, "Talking About Religion: How Highly Religious Youth and Parents Discuss Their Faith," Journal of Adolescent Research 23, no. 5 (September 2008): 637-639, https://doi. org/10.1177/0743558408322141. 
Kristen usia 14-18 tahun di Kanada menunjukkan bahwa dukungan orang tua memiliki hubungan yang kuat dengan religiositas remaja, walaupun hal tersebut dimediasi oleh adanya dukungan iman dari teman sebaya yang juga berkorelasi kuat dengan religiositas remaja. Sekalipun peran teman sebaya menunjukkan hubungan yang lebih kuat dengan religiositas remaja, hal ini tidak berarti bahwa peran orang tua dalam perkembangan iman individu lemah. Orang tua tetap menjadi faktor yang kuat bagi religiositas remaja karena dengan adanya dukungan iman orang tua yang telah diterima terlebih dulu, remaja lebih dapat memaknai dukungan iman yang diberikan teman sebaya. ${ }^{102}$

Orang tua memiliki kelebihan yang tidak dimiliki oleh agen sosialisasi lain dalam meneruskan nilai-nilai dan keyakinan religius. Dalam keluarga, orang tua memiliki kesempatan untuk membesarkan anak menurut ajaran agamanya sehingga anak menerima pola pendidikan serta nilai-nilai menurut keyakinan iman agama yang dianut orang tuanya, dan hal ini tanpa sadar menjadi bagian hidup anak bahkan ketika anak menjadi semakin dewasa. ${ }^{103}$ Proses transmisi yang dialami anak dengan mengamati perilaku religius orang tuanya menjadi prediktor terkuat bagi perilaku dan nilai-nilai religius yang dianut remaja sampai beranjak dewasa. ${ }^{104}$

Dukungan melalui proses transaksi antara orang tua dan anak juga berdampak bagi perilaku religius pemuda. Walaupun pola komunikasi yang terjadi antara pemuda dengan orang tua mengalami perubahan jika dibandingkan dengan saat mereka masih kanakkanak dan remaja, namun dampak komunikasi ini tetap ada. Interaksi dan diskusi yang terjadi dalam keluarga membentuk internalisasi nilai-nilai dan keyakinan iman agama dari orang tua kepada anak, khususnya komunikasi dua arah yang bersifat terbuka, yang memberi kebebasan kepada pemuda untuk

\footnotetext{
${ }^{102}$ Schwartz, "RESEARCH," 320-321.

${ }^{103}$ Vermeer, "Religion and Family Life," 404-405.

${ }^{104}$ Flor dan Knapp, "Transmission and Transaction," 641.
}

memulai, mengarahkan, dan berkontribusi dalam diskusi. Cara-cara demikian dianggap lebih menarik bagi mereka sehingga dapat terlibat aktif dalam topik pembicaraan seputar iman religius. ${ }^{105}$ Melalui percakapan dialogis dengan orang tua, maka pemuda mengalami proses transaksi yang dipercaya dapat memberikan dukungan terhadap perkembangan iman mereka.

Persepsi pemuda tentang dukungan iman yang diterimanya dari orang tua juga ditemukan sebagai prediktor bagi religiositas intrinsik. ${ }^{106}$ Religiositas intrinsik yang tinggi pada pemuda ternyata berhubungan dengan dukungan iman yang diterimanya dari orang tua. Penelitian mengenai dukungan iman yang secara khusus diteliti secara terpisah antara dukungan dari ayah dan ibu menunjukkan bahwa baik ayah maupun ibu berperan penting dalam hal transmisi keyakinan dan praktik religius kepada anak-anaknya, baik laki-laki maupun perempuan. ${ }^{107}$ Selain itu, disebutkan juga bahwa dampak dari ibu lebih kuat kepada anak-anaknya jika dibandingkan dengan dampak dari ayah. Hal ini dapat terjadi karena pada umumnya ibu lebih sering menyosialisasikan kepada anak-anaknya untuk percaya dan mempraktikkan keyakinan iman yang sama seperti dirinya. Dengan demikian, hal ini membentuk ide yang serupa pada anak yang kemudian disertai dengan perilaku religius. ${ }^{108}$

\section{Pandangan Alkitab tentang Dukungan Iman dan Kelekatan}

Ada dua perikop Alkitab yang secara khusus akan dibahas berkaitan dengan peran penting yang diemban orang tua dalam mewariskan

${ }^{105}$ Dollahite dan Thatcher, "Talking About Religion," 638.

${ }^{106}$ Leonard et al., "Parent-Child Dynamics," 9.

${ }^{107}$ Wan Ning Bao dkk., "Perceived Parental Acceptance As A Moderator of Religious Transmission Among Adolescent Boys and Girls," Journal of Marriage and Family 61, no. 2 (Mei 1999): 370, https://doi.org/10.2307/353754.

${ }^{108}$ Lisa D. Pearce dan Arland Thornton, "Religious Identity and Family Ideologies in the Transition to Adulthood," Journal of Marriage and Family 69, no. 5 (Desember 2007): 1228, https://doi.org/10.1111/j.1741-3737.2007.00443.x. 
iman kepada anak-anak mereka. Yang pertama adalah perintah Allah kepada umat Israel melalui Musa dalam Ulangan 6:4-9. Yang kedua adalah nasihat rasul Paulus kepada jemaat di Kota Efesus dalam surat Efesus 6:4.

\section{Perintah Tuhan kepada Orang Tua dalam Ulangan 6:4-9}

Dalam Ulangan 6:4-9 terkandung kebenaran dasar agama Israel bahwa Allah itu esa (ay. 4), dan kewajiban dasar umat Israel untuk mengasihi Allah sesuai kehendak-Nya (ay. 5). Kedua hal tersebut kemudian dihubungkan dengan komunitas umat Israel pada ayat 6-9, secara khusus dalam ranah kehidupan berkeluarga. Setiap orang dewasa sebagai anggota komunitas harus memahami apa yang tertulis dalam kitab Ulangan dan mengajarkannya dengan tekun kepada anak-anak agar firman Allah terus dikomunikasikan dalam keluarga. ${ }^{109}$ Hukum dasar ini dimaksudkan agar bangsa Israel memegang teguh imannya kepada Yahweh, baik generasi saat itu maupun generasi yang akan datang. Oleh karena itu, penekanan pada pengajaran kepada anakanak menjadi konteks yang penting agar hukum Allah tetap dipegang dan terpelihara dalam kehidupan bangsa Israel. ${ }^{110}$

Dalam tradisi Yahudi, ayat 4-5 dikenal dengan sebutan עִַּ̣ (shema, dengarlah) sebagai simbol Yudaisme yang paling penting. Oleh karena itu, orang Yahudi ortodoks mengucapkannya setiap hari dalam doa mereka. ${ }^{11}$ Pada ayat 4 tertulis, "Dengarlah, hai orang Israel: TUHAN itu Allah kita, TUHAN itu esa!" Melalui ayat ini, bangsa Israel diperintahkan untuk setia hanya kepada Yahweh saja satusatunya Allah yang telah berhasil melepaskan mereka dari Mesir. ${ }^{112}$ Melalui pembebasan tersebut bangsa Israel mengalami Tuhan yang

\footnotetext{
${ }^{109}$ Duane L. Christensen, Deuteronomy 1 - 11, ed. David A. Hubbard, Glenn W. Barker, dan Bruce Manning Metzger, Word Biblical Commentary (Waco: Word, 1991), 143. ${ }^{110}$ J.G. McConville, Deuteronomy, Apollos Old Testament
Commentary 5 (Downers Grove: InterVarsity, 2002), 139.

${ }^{111}$ Daniel I. Block, Deuteronomy, The NIV Application Commentary (Grand Rapids: Zondervan, 2012), 181.
}

hidup sebagai satu-satunya Allah mereka yang telah menang mengalahkan allah-allah bangsa Mesir. ${ }^{113}$ Dengan memerintahkan hal ini kepada bangsa Israel, Musa ingin melihat respons bangsa Israel, apakah mereka tetap akan menyembah kepada Tuhan saja, atau tergoda dengan allah-allah orang Kanaan pada waktu mereka memasuki Tanah Perjanjian. Respons yang Allah kehendaki dari umat-Nya yang setia berpegang kepada komitmen tersebut adalah ketaatan untuk mengasihi Allah (ay. 5).

Bangsa Israel diperintahkan untuk mengasihi Tuhan, Allah dengan segenap hati, dengan segenap jiwa, dan dengan segenap kekuatan. Kata "hati" di sini dalam bahasa aslinya menggunakan kata לָָרב yang menunjuk bukan pada emosi atau perasaan manusia, melainkan pemikiran, kehendak, dan perhatian manusia sebagai pusat dari keberadaan dan sumber moral manusia. Baik pilihan dan keputusan yang dibuat, serta karakter yang terbentuk, bersumber dari pemikiran dan kehendak manusia. ${ }^{114}$ Kata "jiwa" dalam bahasa Ibrani menggunakan kata נֶּק yang menunjuk kepada bagian terdalam diri manusia, termasuk emosi, keinginan, karakteristik pribadi manusia dengan keunikannya. ${ }^{115}$ Kata "kekuatan" dalam bahasa Ibrani menggunakan kata yang menunjuk pada sisi fisik dengan segala fungsi dan kapasitas manusia. ${ }^{116}$ Maksud dari perintah ini adalah agar umat Israel mengasihi Tuhan dengan segenap keberadaan mereka, sebagaimana Tuhan yang esa dan satusatunya telah menyatakan diri dan mengasihi umat-Nya dengan mengorbankan segenap diri-Nya (ay. 4). ${ }^{117}$

\footnotetext{
${ }^{113}$ Peter C. Craigie, ed., The Book of Deuteronomy, The New International Commentary on The Old Testament (Grand Rapids: Eerdmans, 1976), 169.

${ }^{114}$ Christopher J.H. Wright, Deuteronomy, New International Biblical Commentary, vol. 4 (Peabody: Hendrickson, 1996), 98-99.

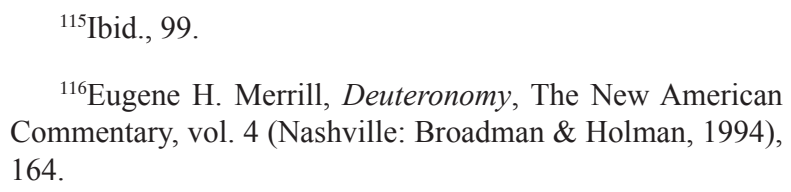

${ }^{116}$ Eugene H. Merrill, Deuteronomy, The New American Commentary, vol. 4 (Nashville: Broadman \& Holman, 1994), 164.

${ }^{117}$ Wright, Deuteronomy, 98.
} 
Selanjutnya pada Ulangan 6:6 disebutkan bahwa seluruh perintah yang disampaikan Musa kepada bangsa Israel harus diperhatikan. Hal ini mengingatkan bahwa hukum Allah harus selalu ada dalam hati, direnungkan dan terinternalisasi menjadi bagian dalam diri mereka. Maksudnya adalah agar bangsa Israel memperhatikan dan menaati hukum Allah dengan sungguh-sungguh, bukan hanya sekadar formalitas. Hal ini berarti mereka diharapkan untuk memberikan respons atas perintah tersebut dengan dasar pengertian yang mendalam dan disertai tanggung jawab untuk mengajarkannya kepada anak-anak mereka (ay. 7). ${ }^{118}$

Perintah Tuhan merupakan prinsip utama yang harus disampaikan melalui pengajaran dan praktik yang dilakukan di dalam rumah tangga atau keluarga Israel. ${ }^{119}$ Dengan menanamkan ajaran perintah Tuhan kepada anak dan mendiskusikannya dengan anggota keluarga, seluruh anggota keluarga Israel menunjukkan komitmennya terhadap perjanjian mereka dengan Tuhan. Penanaman perintah Tuhan (ay. 4-5) kepada anak harus selalu dilakukan secara berulang-ulang (ay. 7). ${ }^{120}$ Perintah Tuhan juga harus menjadi topik pembicaraan orang tua dengan anak baik di dalam rumah maupun di luar rumah, pada waktu memulai hari sampai berakhirnya hari. ${ }^{121} \mathrm{Hal}$ ini menunjukkan bahwa mengajarkan perintah Tuhan kepada anak harus dilakukan pada setiap waktu dan di segala tempat, selalu dan di mana saja. ${ }^{122}$ Baik pada waktu beraktivitas atau tidak beraktivitas, pada waktu bangun pagi hari maupun pada waktu hendak beristirahat di malam hari, perintah Tuhan harus meliputi seluruh kehidupan dan

${ }^{118}$ Christensen, Deuteronomy 1-11, 144.

${ }^{119}$ Edesio Sanchez, "Family in The Non-Narrative Sections of The Pentateuch," dalam Family in The Bible: Exploring Custom, Culture, and Context, ed. Richard S. Hess dan M. Daniel Carroll R. (Grand Rapids: Baker Academic, 2003), 51.

\footnotetext{
${ }^{120}$ Block, Deuteronomy, 184.

${ }^{121}$ Craigie, The Book of Deuteronomy, 170.

${ }^{122}$ Richard Nelson, Deuteronomy: A Commentary (Louisville: Westminster John Knox, 2004), 92.
}

menjadi pusat dari kehidupan tiap orang dari umat Israel. ${ }^{123}$

Selain mengajarkannya, setiap orang Israel harus mengikatkannya pada tangan, menjadikannya lambang di dahi, dan menuliskannya di tiang pintu rumah dan pintu gerbang (ay. 8-9). Hal ini mengandung makna kiasan atau metafora. Perintah Tuhan harus diikatkan di tangan dan menjadi lambang di dahi menunjukkan bahwa perintah Tuhan itu harus dipraktikkan dalam kehidupan pribadi masing-masing individu. Perintah Tuhan juga harus dituliskan di tiang pintu rumah sebagai pertanda bahwa perintah tersebut juga dilakukan dalam keluarga. Menuliskan perintah Tuhan di pintu gerbang menggambarkan bahwa perintah Tuhan juga harus dilakukan dalam komunitas atau masyarakat yang lebih luas. Ketiga hal tersebut menunjukkan komitmen kasih kepada Allah secara total yang tampak melalui kehidupan pribadi, keluarga, dan komunitas atau masyarakat umum. ${ }^{124}$ Dengan menaati perintah Tuhan dan perjanjian dengan Allah dalam kehidupan pribadi, keluarga, dan komunitas, bangsa Israel membuktikan kasihnya kepada Allah. ${ }^{125}$

Ketiga hal di atas menjadi pengingat bagi bangsa Israel akan kesetiaan dan kasihnya kepada Yahweh yang memerintah seluruh aktivitas mereka, baik di dalam maupun di luar rumah sehingga orang lain yang bertamu atau yang melewati rumah mereka akan mengetahui Yahweh sebagai kepala keluarga yang juga memerintah kota dan seluruh bangsa Israel. ${ }^{126}$ Dengan demikian, setiap individu beserta seluruh keluarga dan komunitasnya akan dikenali identitasnya sebagai umat Tuhan. ${ }^{127}$ Karena perintah Tuhan ini begitu penting bagi identitas bangsa Isarel, pengajaran dan praktiknya harus dimulai dari dalam keluarga melalui orang tua.

\footnotetext{
${ }^{123}$ Merrill, Deuteronomy, 167.

${ }^{124}$ Wright, Deuteronomy, 100.

${ }^{125}$ Craigie, The Book of Deuteronomy, 171.

${ }^{126}$ Block, Deuteronomy, 186.

${ }^{127}$ Merrill, Deuteronomy, 168.
} 
Dalam keluarga Israel yang menganut sistem keluarga patriarkal, ayah memegang otoritas penuh dan memerintah atas seluruh anggota keluarga. ${ }^{128}$ Anggota keluarga Israel tidak hanya terdiri dari ayah, ibu, dan anak, tetapi merupakan keluarga besar yang di dalamnya terdapat juga keluarga dari anak yang telah menikah dan memiliki keturunan. Anak yang sudah dewasa pun harus mendengarkan pengajaran dari ayah yang senior dalam rumah tangga multigenerasi tersebut serta mengajarkannya kepada anak-anak mereka. ${ }^{129}$

Selain mengajarkan tradisi dan aktivitas ritual religius, mengajarkan perintah Tuhan (yang tercatat dalam Ul. 6:4-9) menjadi tugas dan tanggung jawab utama para ayah keluarga Israel. Hal ini dimaksudkan untuk menjaga kesatuan seisi rumah tangga dan warisan keluarga Israel yang diturunkan dari para leluhur yang telah menerima perintah tersebut pada waktu Musa mengatakannya. ${ }^{130}$ Para ayah keluarga Israel bertanggung jawab untuk meneruskan warisan iman kepada keturunannya, terutama kepada anak laki-laki dengan maksud agar anak laki-lakinya kelak meneruskan warisan tersebut kepada keturunan selanjutnya. Dengan demikian, perintah Tuhan tersebut terus terpelihara dalam sepanjang sejarah bangsa Israel. ${ }^{131}$

Pentingnya mengajarkan perintah Tuhan kepada anak tidak hanya berhenti pada Ulangan 6:4-9, melainkan juga terus digemakan sepanjang sejarah Israel. Dalam kitab Amsal terdapat nasihat mengenai pengajaran orang tua kepada anak (Ams. 1-9). Walaupun pengajaran dalam kitab Amsal umumnya dilakukan

${ }^{128}$ Daniel I. Block, "Marriage and Family in Ancient Israel," dalam Marriage and Family in The Biblical World, ed. Ken M. Campbell (Downers Grove: InterVarsity, 2003), $40-41$.

${ }^{129}$ Carol Meyers, "The Family in Early Israel," dalam Families in Ancient Israel, ed. Leo G. Perdue, ed. ke-1 (Louisville: Westminster John Knox, 1997), 31.

${ }^{130}$ Ibid., 32.

${ }^{131}$ James M. Hamilton Jr., "That The Coming Generation Might Praise The Lord: Family Discipleship in The Old Testament," dalam Trained In The Fear of God, ed. Randy Pinson dan Timothy P. Jones (Grand Rapids: Kregel, 2011), 34-35. oleh ayah, ayat-ayat tersebut menunjukkan bahwa ayah berbicara mewakili kedua belah pihak orang tua ketika mengajar anak sehingga dapat dikatakan bahwa kedua orang tua terlibat di dalamnya. ${ }^{132}$

Mengajarkan perintah Tuhan kepada anak merupakan tanggung jawab orang tua dalam keluarga orang Yahudi. Hal ini terutama tampak melalui kitab Ulangan, kitab pengajaran bagi bangsa Israel yang memberikan titik tolak bagi pembelajaran iman dalam sistem keluarga sejak awal mula kehidupan. Tujuan pengajaran ini adalah agar umat Israel menyembah hanya kepada Tuhan sejak masa kanak-kanak, dewasa dan sampai akhir hidupnya. ${ }^{133}$

\section{Nasihat Paulus mengenai Peran Orang Tua dalam Efesus 6:4}

Efesus 6:4 terdapat dalam bagian besar Efesus 5:22-6:9 yang di dalamnya Paulus menyampaikan nasihat mengenai aturan rumah tangga kepada anggota-anggota keluarga Kristen yang ada di Efesus. Aturan rumah tangga Kristen ini diberikan agar setiap anggota keluarga Kristen dapat memahami bagaimana seharusnya mereka berpikir dan bertindak sebagai orang percaya dalam menjalankan peran masing-masing. Hal ini dapat dicapai dengan dasar berfokus dan motivasi utama untuk menyenangkan Tuhan serta memperoleh pengenalan akan Tuhan. ${ }^{134}$ Paulus menasihati jemaat perihal hubungan di antara penghuni rumah tangga, khususnya anak dengan orang tua (6:1-4), serta hamba dengan tuannya (6:5-9). ${ }^{135}$ Struktur perikop ini terbagi dalam empat bagian, yaitu nasihat untuk

\footnotetext{
${ }^{132}$ Tremper Longman III, "Family in The Wisdom Literature," dalam Family in The Bible: Exploring Custom, Culture, and Context, ed. Richard S. Hess dan M. Daniel Carroll R. (Grand Rapids: Baker Academic, 2003), 84.

${ }^{133}$ Patrick D. Miller, "That The Children May Know: Children in Deuteronomy," dalam The Child in The Bible, ed. Marcia J. Bunge, Terence E. Fretheim, dan Beverly R. Gaventa (Grand Rapids: Eerdmans, 2008), 62.

${ }^{134}$ Clinton E. Arnold, Ephesians, Zondervan Exegetical Commentary Series on The New Testament v. 10 (Grand Rapids: Zondervan, 2010), 413.

${ }^{135}$ Ibid., 411.
} 
anak (6:1a), ayah (6:4a), hamba (6:5a), dan tuan $(6: 9 a){ }^{136}$

Efesus 6:4 terdapat pada bagian kedua setelah Paulus menuliskan nasihat yang ditujukan kepada anak-anak, ${ }^{137}$ yang diawali dengan kata "dan kamu, bapa-bapa" yang menunjukkan bahwa tanggung jawab ayah ini masih berhubungan dekat dengan tanggung jawab anak yang disampaikan Paulus pada ayat sebelumnya. ${ }^{138}$ Ayat sebelumnya menasihatkan kepada anak-anak untuk taat kepada orang tua, yaitu ayah dan ibu, namun pada ayat ini nasihat Paulus disebutkan hanya untuk ayah saja. Memang kata "bapa-bapa" di sini bisa berarti termasuk dengan ibu juga, tetapi Paulus mengkhususkannya kepada para ayah yang dianggap memiliki otoritas mutlak atas anaknya dan bertanggung jawab dalam pendidikan anak. ${ }^{139} \mathrm{Hal}$ ini tidak hanya berlaku bagi orang Yahudi, tetapi juga orang bukan Yahudi yang ada di Efesus. Latar belakang penduduk Efesus menjadi alasan Paulus memberikan nasihat kepada ayah. Masyarakat YudaismeHelenistik menganut struktur keluarga patriarkal, begitu pula orang Yunani-Romawi yang mengakui ayah sebagai pemegang kekuasaan dalam keluarga (disebut dengan istilah patria potestas). ${ }^{140}$

Paulus menasihatkan para ayah "janganlah bangkitkan amarah di dalam hati anak-anakmu." Frasa "jangan bangkitkan amarah" memiliki asal kata yaitu $\mu \grave{\eta} \pi \alpha \rho o \rho \gamma i ́ \zeta \varepsilon \tau \varepsilon$. Kata $\mu \grave{\eta}$ merupakan bentuk larangan dalam klausa bebas, untuk mengekspresikan harapan negatif atau peringatan. ${ }^{141}$ Kata $\pi \alpha \rho o \rho \gamma i ́ \zeta \varepsilon \tau \varepsilon$ berasal dari kata kerja $\pi \alpha \rho o \rho \gamma i \zeta \omega$. Kata $\pi \alpha \rho o \rho \gamma i \zeta \omega$ sendiri adalah gabungan dari dua kata, yaitu

\footnotetext{
${ }^{136}$ Arnold, Ephesians, 413.

${ }^{137}$ Ibid.

${ }^{138}$ Harold W. Hoehner, Ephesians: An Exegetical Commentary (Grand Rapids: Baker Academic, 2002), 794.

${ }^{139}$ Klyne Snodgrass, Ephesians, The NIV Application Commentary (Grand Rapids: Zondervan, 1996), 322.

${ }^{140}$ Hoehner, Ephesians, 795.

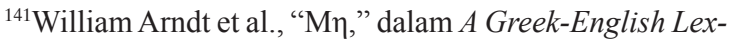
icon of The New Testament and Other Early Christian Literature (Chicago: University of Chicago Press, 1979), 516.
}

$\pi \alpha \rho \alpha$ dan o $\rho 1 \zeta$. Kata $\pi \alpha \rho \alpha$ merupakan bentuk kata preposisi yang dapat ditempatkan bersamaan dengan kata benda, kata sifat, dan kata kerja, dan dapat diartikan sebagai di samping, oleh, dengan, dari, di luar, ${ }^{142}$ sedang-

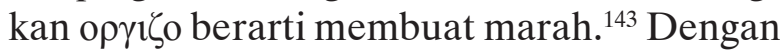
demikian, kata $\mu$ ì $\pi \alpha \rho \rho \rho \gamma \dot{\zeta} \varepsilon \tau \varepsilon$ yang terdapat dalam ayat ini berarti "jangan membangkitkan amarah."

Nasihat tersebut terkait dengan nasihat Paulus sebelumnya tentang "amarah" dalam 4:2627, 31 yang menggunakan kata $\pi \alpha \rho o \rho \gamma ı \sigma \mu o ́ s$

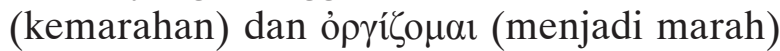
yang sama asal katanya dengan $\pi \alpha \rho \rho \rho \gamma \zeta \omega$ (membangkitkan amarah). ${ }^{144}$ Nasihat ini berbentuk larangan dengan maksud supaya ayah tidak membangkitkan amarah anaknya melalui kata-kata yang kasar, maupun melalui tindakan sarkasme, merendahkan, mengganggu secara tidak pantas, bertengkar, menuntut tanpa alasan, atau segala sesuatu yang dapat memprovokasi timbulnya kemarahan pada anak. ${ }^{145}$ Sebaliknya ayah sepatutnya memperlakukan anak dengan sabar dan lembut, ${ }^{146}$ serta berhati-hati dan membiasakan dirinya untuk tidak memperlakukan anaknya demikian. ${ }^{147}$ Ayah perlu melatih kepekaan dan kepedulian dalam interaksinya dengan anak, secara khusus dalam mengajar mereka. ${ }^{148}$

Paulus tidak berhenti pada nasihat yang bernada negatif tersebut. Dalam Efesus 6:4b Paulus melanjutkan dengan nasihat yang bernada positif, "tetapi didiklah mereka di dalam

\footnotetext{
${ }^{142}$ Riesenfeld, " $\pi \alpha \rho \alpha, "$ dalam Theological Dictionary of The New Testament, ed. Gerhard Kittel, terj. Geoffrey W. Bromiley (Grand Rapids: Eerdmans, 1967), 728-736.

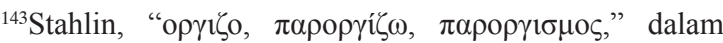
Theological Dictionary of The New Testament, ed. Gerhard Kittel, terj. Geoffrey W. Bromiley (Grand Rapids: Eerdmans, 1967), 410

${ }^{144}$ Peter T. O'Brien, Surat Efesus, terj. Andri Kosasih (Surabaya: Momentum, 2013), 536.

${ }^{145}$ Arnold, Ephesians, 418.

${ }^{146}$ O’Brien, Surat Efesus, 544.

${ }^{147}$ Andrew T. Lincoln, Ephesians, Word Biblical Commentary 42 (Dallas: Word, 2005), 407.

${ }^{148}$ Arnold, Ephesians, 417.
} 
ajaran dan nasihat Tuhan." Kata "tetapi" digunakan untuk menunjukkan adanya sesuatu yang kontras dari pernyataan awal yang negatif dengan pernyataan selanjutnya yang positif. ${ }^{149}$ Pada nasihat yang bernada positif ini, kata "didiklah" menggunakan kata Yunani

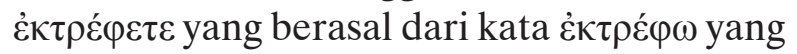
berarti memelihara, mendidik, atau mengasuh anak. ${ }^{150}$ Kata ini mengandung dua unsur, yaitu kata غ̇א yang berarti "dari, di luar dari" dan kata $\tau \rho \varepsilon \dot{\varphi} \omega$ yang mengandung arti mengasuh, memberi makan, memelihara, ${ }^{151}$ dan melatih anak kepada pertumbuhan. ${ }^{152}$ Ayah dinasihati agar mendidik dan membesarkan anaknya hingga mencapai kematangan, bukan hanya supaya anak bertumbuh menjadi orang yang sopan dan bertanggung jawab, tetapi juga melatih dan mengajar anak dalam jalan Tuhan. ${ }^{153}$

Paulus menasihatkan para ayah untuk mendidik anaknya dalam ajaran dan nasihat Tuhan.

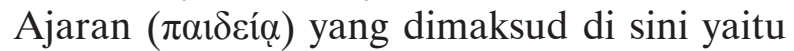
pendidikan atau pelatihan yang diberikan sebagai upaya untuk membawa anak kepada

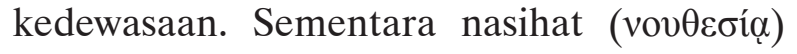
merupakan bentuk teguran atau koreksi verbal, ${ }^{154}$ termasuk menasihati tentang perilaku, memberi peringatan, bahkan memarahi. ${ }^{155}$ Dalam ayat ini, teguran yang dimaksud tentunya diberikan tanpa menimbulkan amarah pada anak. ${ }^{156}$ Baik ajaran maupun nasihat memiliki makna yang identik menurut asal

\footnotetext{
${ }^{149}$ Hoehner, Ephesians, 796.

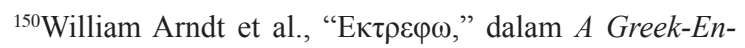
glish Lexicon of The New Testament and Other Early Christian Literature (Chicago: University of Chicago Press, 1979), 246.

${ }^{151}$ W.E. Vine, Merrill F. Unger, dan William White, Vine's Complete Expository Dictionary of Old and New Testament Words (Nashville: T. Nelson, 1996), 435.

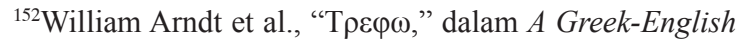
Lexicon of The New Testament and Other Early Christian Literature (Chicago: University of Chicago Press, 1979), 825.

${ }^{153}$ Arnold, Ephesians, 418.

${ }^{154}$ O’Brien, Surat Efesus, 543-544.

${ }^{155}$ Arnold, Ephesians, 418.

${ }^{156}$ Hoehner, Ephesians, 797.
}

katanya sehingga sulit untuk membedakan keduanya, namun ajaran dapat dipahami sebagai aktivitas dan disiplin, sedangkan nasihat sebagai aspek verbal dari pendidikan yang memberikan dorongan. ${ }^{157}$

Ajaran dan nasihat yang diberikan oleh ayah dikatakan berasal dari Tuhan. Hal ini berarti pengajaran maupun nasihat yang diberikan ayah bukanlah seperti pendidikan pada umumnya, melainkan pendidikan yang mengajarkan tradisi para rasul tentang Kristus dan menolong pembentukan kehidupan anak sesuai dengan pengajaran Kristus. ${ }^{158}$

Dalam mengajarkan tentang Kristus kepada anaknya, para ayah diharapkan tidak berfokus pada ketaatan anak pada otoritas mereka, melainkan pada pertumbuhan dan pengenalan pribadi anak akan Kristus sendiri melalui ajaran dan nasihat yang mereka berikan. ${ }^{159}$ Selain itu, melalui teladan sikap hidup ayah yang sesuai pengajaran Kristus, pengajaran yang diberikan melalui kata-kata kepada anak dapat lebih efektif diterima dan diteladani anak. ${ }^{160}$ Oleh karena itu, ayah perlu belajar mengenal Kristus dan menerima kebenaran yang nyata dalam Kristus sebagaimana dinasihatkan Paulus sebelumnya (4:20-21). ${ }^{161}$

Para ayah haruslah bergantung pada Roh Kudus untuk melembutkan sikap dan perilaku mereka, memampukan mereka untuk tidak bersikap atau berperilaku yang dapat menimbulkan amarah atau sakit hati anak, serta dapat melatih dan mengajar anak mereka dengan hikmat dan kemampuan dari Roh Kudus sehingga tercapai suatu hubungan yang harmonis antara orang tua dan anak. ${ }^{162}$

Melalui nasihat Paulus, para ayah Kristen dipanggil untuk tidak membangkitkan amarah anak dan mendidik anak dalam ajaran dan

\footnotetext{
${ }^{157}$ Hoehner, Ephesians, 798.

${ }^{158}$ Lincoln et al., Ephesians, 408.

${ }^{159}$ O’Brien, Surat Efesus, 544.

${ }^{160}$ Lincoln et al., Ephesians, 409.

${ }^{161} \mathrm{O}$ 'Brien, Surat Efesus, 544.

${ }^{162}$ Hoehner, Ephesians, 799.
} 
nasihat Tuhan dengan didasari oleh motivasi yang terarah sepenuhnya kepada Kristus. ${ }^{163}$ Dengan demikian, setiap ayah dalam keluarga Kristen patut menjalankan kewajibannya untuk melakukan hal ini dengan sungguhsungguh sebagai bentuk kesetiaannya kepada ketuhanan Yesus Kristus. ${ }^{164}$

\section{Prinsip Alkitabiah mengenai Peran Orang Tua terhadap Pertumbuhan Iman Anak}

Teks Alkitab yang telah dijelaskan di atas menyediakan beberapa prinsip alkitabiah berkaitan dengan peran orang tua bagi pertumbuhan iman anak.

Pertama, orang tua berperan dalam meneruskan iman kepada anak-anaknya. Peran ini dilakukan dengan cara orang tua mengajarkan tentang perintah Tuhan agar anak mengerti dan menaati perintah tersebut dalam kehidupan mereka. Perintah utama yang harus menjadi pusat kehidupan setiap orang percaya dan diajarkan kepada keturunannya yaitu perintah untuk mengasihi Tuhan dengan segenap hati, jiwa, dan kekuatan (Ul. 6:5; Tuhan Yesus menyebutkan kembali dalam Mat. 22:37 dan Mrk. 12:30). Perintah yang utama ini berlaku bagi setiap orang percaya. Setiap orang tua harus menaatinya dan harus mengajarkannya kepada anak-anak mereka. Melalui perintah ini, anak-anak belajar untuk mengasihi Tuhan dengan seluruh keberadaannya. Apabila perintah Tuhan ini telah terinternalisasi dalam diri, anak menaati perintah Tuhan ini sebagai bukti kasih dan komitmennya kepada Tuhan, yang seharusnya mendasari cara hidup serta ibadahnya kepada Tuhan.

Kedua, orang tua berkewajiban untuk mendidik anaknya menuju kedewasaan menurut ajaran dan nasihat yang bersumber dari firman Tuhan (Ef. 6:4b). Melalui kebenaran firman Tuhan, anak belajar dan menerima disiplin untuk hidup sesuai firman Tuhan. Apabila anak menyimpang dari jalan yang benar, maka orang tua bertanggung jawab untuk menasihatinya, baik dengan teguran secara

\footnotetext{
${ }^{163}$ Lincoln et al., Ephesians, 407.

${ }^{164} \mathrm{O}$ 'Brien, Surat Efesus, 544
}

verbal atau bahkan menghukumnya. Hal ini dilakukan semata-mata untuk kebaikan, supaya anak bertobat dan kembali kepada jalan yang benar sesuai firman Tuhan.

Ketiga, setiap bentuk didikan dan disiplin yang diberikan orang tua kepada anak perlu dilakukan secara konsisten (Ul. 6:7-9). Orang tua harus konsisten dalam membicarakan firman Tuhan serta melakukannya sehingga menjadi teladan yang dapat disaksikan secara langsung oleh anak-anaknya. Orang tua perlu secara terus-menerus dan berulang-ulang melakukan hal tersebut setiap waktu, di segala tempat, dalam semua area kehidupannya, baik kehidupan pribadi, dalam rumah/keluarga, dan bahkan di luar rumah/masyarakat luas. Dengan demikian, anak dapat mencontoh sikap hidup orang tuanya dan juga taat melakukan perintah Tuhan seperti yang dicontohkan oleh orang tuanya.

Keempat, orang tua tidak hanya bertanggung jawab mengajarkan perintah Tuhan saja, tetapi juga menjalin hubungan yang baik dengan anak, yang dicapai melalui sikap, tutur kata, dan perbuatan orang tua kepada anak. Orang tua selayaknya tidak menunjukkan sikap yang meremehkan atau merendahkan anak, berkata-kata dan bertindak sesuatu yang memicu timbulnya sakit hati pada anak (Ef. 6:4a). Perbuatan demikian dapat menimbulkan kemarahan, atau tawar hati pada diri anak yang akan membuatnya lebih sulit menerima ajaran dan didikan orang tuanya. Sebaliknya, orang tua menunjukkan sikap hidup sebagai orang percaya yang mengikuti pengajaran Yesus Kristus dengan menunjukkan kasih, kesabaran, dan kelemahlembutan kepada anak-anaknya.

Oleh karena itu, orang tua perlu memiliki hubungan yang baik dan sehat dengan anaknya melalui perkataan, sikap, dan perbuatan sehingga dengan demikian memberi atmosfer yang mendukung bagi pertumbuhan iman anak. Melalui pertolongan Roh Kudus juga setiap orang tua dimampukan untuk bersikap, berkata-kata, atau bertindak selayaknya orang percaya di hadapan anak-anaknya, dan orang tua dapat menjadi pendidik yang efektif 
dalam mengajarkan dan menasihati anak sesuai firman Tuhan.

\section{METODE PENELITIAN}

Penelitian ini adalah kualitatif untuk mencari hubungan antara kelekatan anak-orangtua dan dukungan iman orangtua sebagai variabel independen dengan religiositas intrinsik sebagai variabel dependen pada pemuda di delapan gereja Injili di Kota Bandung, Jawa Barat. Dari populasi tersebut, diambil sampel penelitian dengan teknik nonprobability sampling dan convenience sampling dengan kriteria usia 18-29 tahun dan belum menikah. Sampel berjumlah 226 yang terdiri dari 117 perempuan dan 109 laki-laki.

\section{Instrumen}

Religiositas intrinsik diukur melalui Intrinsic Revised yang diambil dari I/E-Revised Scale. Instrumen ini terdiri dari 5 item positif dan 3 item negatif. Penilaian menggunakan 6 poin skala Likert $(1=$ sangat tidak setuju, $2=$ tidak setuju, $3=$ agak tidak setuju, $4=$ agak setuju, $5=$ setuju, $6=$ sangat setuju). ${ }^{165}$ Intrinsic Revised Scale memiliki konsistensi internal yang tinggi, dengan nilai reliabilitas $0,83 .{ }^{166}$ Validitas kriteria instrumen ini telah teruji melalui pengukuran korelasi dengan alat ukur komitmen religius lain dan hasilnya menunjukkan korelasi yang baik, yaitu $0,76{ }^{167}$

Kelekatan pemuda-orang tua diukur melalui Inventory of Parent and Peer Attachment (IPPA). ${ }^{168}$ Instrumen ini terdiri dari 12 item kelekatan dengan ayah dan 12 item kelekatan dengan ibu. IPPA memiliki nilai reliabilitas yang tinggi, yaitu 0,82 untuk skala orang

\footnotetext{
${ }^{165}$ Richard L. Gorsuch dan Susan E. McPherson, "Intrinsic/Extrinsic Measurement: I/E-Revised and Single-Item Scales," Journal for the Scientific Study of Religion 28, no. 3 (September 1989): 352, https://doi. org/10.2307/1386745.

${ }^{166}$ Ibid.

${ }^{167}$ Donahue, "Intrinsic and Extrinsic Religiousness," 405.

${ }^{168}$ Shyamala N. Raja, Rob McGee, dan Warren R. Stanton, "Perceived Attachments to Parents and Peers and Psychological Well-Being in Adolescence," Journal of Youth and Adolescence 21, no. 4 (Agustus 1992): 475.
}

tua. ${ }^{169}$ Koefisien korelasi antar-item pada subskala komunikasi dan kepercayaan terhadap orang tua dinyatakan dengan nilai $\mathrm{r}=0.67$, yang berarti tinggi dan signifikan untuk mengukur kelekatan dengan orang tua. ${ }^{170}$

Dukungan iman diukur menggunakan instrumen Perceived Faith Support-Parent Scale (PFS-P), yang mengukur seberapa tinggi dukungan iman yang diterima subjek dari orang tuanya. ${ }^{171}$ Instrumen ini terdiri dari 8 item pernyataan mengenai dukungan iman yang diterima dari orang tua, baik ayah maupun ibu, sehingga keseluruhan berjumlah 16 item. PFS-P memiliki nilai reliabilitas alat ukur yang tinggi, yaitu 0,86 untuk dialog iman, dan 0,90 untuk pemodelan iman. ${ }^{172}$ Instrumen ini dinyatakan valid dan reliabel untuk mengukur faktor dukungan dari orang tua dalam perkembangan iman individu. ${ }^{173}$

\section{Prosedur}

Pertama, instrumen yang akan digunakan sebagai alat ukur diterjemahkan ke dalam Bahasa Indonesia. Hasil terjemahan tersebut diuji coba kepada mahasiswa tingkat dua STT SAAT untuk menilai ada atau tidaknya itemitem yang tidak atau sulit dimengerti oleh responden. Hasil uji coba tersebut kemudian dievaluasi dan direvisi. Kedua, peneliti mengurus surat perizinan untuk melakukan penelitian di beberapa gereja Injili di Kota Bandung, dan menyerahkannya kepada pihak terkait, kemudian peneliti melakukan pengambilan data di lapangan sesuai izin yang diberikan. Ketiga, peneliti mengumpulkan data melalui bantuan pembina pemuda di gereja. Keempat, data yang sudah diperoleh kemudian diterjemahkan ke dalam bentuk kode-kode, dan dilakukan perhitungan data statistik menggunakan teknik analisis data Spearman Rank Coefficient melalui program IBM SPSS 20.0.

\footnotetext{
${ }^{169}$ Ibid.

${ }^{170}$ Ibid., 482.

${ }^{171}$ Schwartz, “RESEARCH,” 318.

${ }^{172}$ Ibid., 317.

${ }^{173}$ Ibid., 324.
} 
Peneliti juga menguji kembali validitas dan reliabilitas alat ukur yang telah diterapkan kepada sampel penelitian ini. Kelima, peneliti melakukan analisis terhadap hasil olahan data, mendiskusikan hasil penelitian, serta menyusun laporan akhir penelitian.

\section{Keterbatasan Penelitian}

Keterbatasan yang pertama berkaitan dengan teknik pengambilan sampel yang dilakukan secara konvenien. Sampel diambil berdasarkan kemudahan peneliti dalam menjangkau gereja-gereja Injili di Kota Bandung sehingga terbatas hanya pada karakteristik gereja tertentu. Data yang diperoleh juga tidak tersebar secara merata di masing-masing gereja yang menjadi populasi penelitian sehingga hasil pengolahan data juga tidak menggambarkan keunikan tertentu pada masing-masing gereja Injili yang menjadi populasi penelitian.

Kedua, dalam pengambilan sampel, peneliti tidak secara langsung menemui seluruh responden. Oleh karena adanya keterbatasan waktu untuk mengumpulkan responden selain hari Minggu maka dengan kesepakatan pembina pemuda di gereja, peneliti menyebarkan kuesioner melalui bantuan pembina pemuda di gereja. Kondisi ini membuat peneliti tidak dapat mengontrol jalannya pengambilan data secara langsung.

Ketiga, penelitian ini tidak menjaring informasi tentang status responden sebagai mahasiswa yang sedang kuliah, kuliah sambil bekerja, atau sudah bekerja pada bagian demografi. Selain itu, data mengenai ada tidaknya pembinaan rohani yang diterima responden di gereja dan figur siapa yang paling dirasakan perannya dalam membina kerohanian pemuda di gereja dapat turut menunjang hasil penelitian ini.

\section{HASIL PENELITIAN}

Profil responden adalah sebagai berikut: Dari keseluruhan responden terdapat 117 perempuan $(51,8 \%)$ dan 109 laki-laki $(48,2 \%)$. Mayoritas responden merupakan suku Tionghoa, sebanyak 172 orang $(76,1 \%)$.
Sedangkan 38 orang $(16,8 \%)$ merupakan suku-suku lain, di antaranya suku Sunda, Jawa, Batak, Toraja, Kupang, Minahasa, Dayak, Papua, Ambon, Flores, dan Timor. Sisanya 16 orang $(7,1 \%)$ merupakan campuran antara Jawa-Tionghoa, Sunda-Tionghoa, Batak-Tionghoa, serta Manado-Tionghoa. Mayoritas responden memiliki kedua orang tua yang beragama Kristen Protestan, yaitu sebanyak 195 orang $(86,3 \%)$. Sedangkan sisanya sebanyak 11 orang $(4,9 \%)$ hanya salah satu orang tuanya Kristen Protestan, 11 orang $(4,9 \%)$ kedua orang tuanya bukan beragama Kristen Protestan, 7 orang $(3,1 \%)$ orang tuanya beragama Katolik, dan 2 orang $(0,9 \%)$ orang tuanya tidak beragama.

Berdasarkan hasil analisis korelasi Spearman's rho, kelekatan ayah dengan religiositas intrinsik tidak berkorelasi secara signifikan ( $\mathrm{p}$ $>0,05[\mathrm{p}=0,444]$ dan $\left.R^{2}=0,002\right)$. Dengan demikian hipotesis penelitian yang menyebutkan adanya hubungan antara kelekatan pemuda-ayah dengan religiositas intrinsik ditolak.

Hasil analisis korelasi antara kelekatan ibu dengan religiositas intrinsik menunjukkan adanya korelasi yang signifikan, meskipun derajatnya lemah $(\mathrm{p}<0,05[\mathrm{p}=0,011]$, dengan koefisien korelasi $\mathrm{r}=0,170$ dan $\left.R^{2}=0,029\right)$. Korelasi tersebut juga bersifat positif. Dengan demikian hipotesis yang menyebutkan adanya hubungan antara kelekatan pemuda-ibu dengan religiositas intrinsik diterima.

Hasil analisis korelasi Spearman antara dukungan iman ayah dengan religiositas intrinsik menunjukkan tidak adanya korelasi secara signifikan $\left(\mathrm{p}>0,05[\mathrm{p}=0,251]\right.$ dan $R^{2}$ $=0,006)$. Hal serupa terlihat juga dari hasil analisis korelasi Spearman's rho antara dukungan iman ibu dengan religiositas intrinsik yang tidak menunjukkan adanya korelasi yang signifikan $\left(\mathrm{p}>0,05[\mathrm{p}=0,334]\right.$ dan $R^{2}=$ $0,004)$. Dengan demikian, hipotesis penelitian yang menyebutkan adanya hubungan antara dukungan iman orang tua, baik ayah maupun ibu, dengan religiositas intrinsik ditolak. 


\section{DISKUSI HASIL PENELITIAN}

Tidak adanya hubungan antara kelekatan pemuda-ayah dengan religiositas intrinsik pemuda dapat dijelaskan melalui beberapa faktor.

Pertama, faktor religiositas orang tua. Pada penelitian Granqvist terhadap mahasiswa di Swedia ditemukan adanya hubungan antara kelekatan pemuda-orang tua dan religiositas pemuda, namun hal tersebut ternyata dimediasi juga dengan tingkat religiositas orang tua (baik ayah maupun ibu). ${ }^{174}$ Penelitian tersebut menyebutkan bahwa pemuda yang lekat dengan orang tuanya yang juga memiliki religiositas yang tinggi, dapat diprediksi religiositasnya pun akan tinggi, dan sebaliknya. Hal ini berarti kelekatan pemuda-orang tua tidak secara langsung berhubungan dengan religiositas pemuda. Hubungan dapat terjadi ketika tingkat religiositas orang tua juga diukur. Kelekatan pemuda dengan orang tua yang memiliki religiositas tinggi akan memungkinkan religiositas yang tinggi juga pada pemuda. Dalam penelitian ini tidak dilakukan pengukuran terhadap religiositas orang tua sehingga tidak dapat dikatakan secara pasti tingkat religiositas orang tua responden.

Kedua, faktor kesamaan dengan keyakinan religius ayah. Tidak adanya hubungan antara kelekatan pemuda-ayah dengan religiositas intrinsik pada penelitian ini kemungkinan karena ada faktor lain yang tidak terukur, yaitu kesamaan dengan keyakinan religius ayah. Hasil penemuan dari penelitian Leonard dan kawan-kawan mengenai dinamika relasi orang tua-anak dan religiositas pada pemuda menyebutkan bahwa kelekatan dengan ayah tidak dapat memprediksi religiositas intrinsik pemuda kecuali jika disertai pengukuran terhadap kesamaan dengan keyakinan religius ayah. ${ }^{175}$ Dengan mengetahui kesamaan keyakinan antara pemuda dengan ayahnya maka religiositas intrinsik pemuda pun dapat diprediksi. Berdasarkan hasil penelitian ini

\footnotetext{
357.

${ }^{174}$ Granqvist, "Religiousness and Perceived Childhood,"

${ }^{175}$ Leonard et al., "Parent-Child Dynamics," 12.
}

kemungkinan tidak terdapat kesamaan keyakinan di antara ayah dan anak sehingga tidak terdapat hubungan antara kelekatan pemudaayah dengan religiositas intrinsiknya, namun hal tersebut tidak terukur melalui penelitian ini dan memerlukan penyelidikan lebih jauh.

Ketiga, karakteristik nilai dalam keluarga Tionghoa yang cenderung tidak lekat dengan figur otoritas dalam keluarga. Mayoritas responden dalam penelitian ini merupakan keturunan Tionghoa sehingga nilai-nilai budaya Tionghoa yang terdapat dalam keluarga responden dapat mewarnai hubungan antara anak dengan orang tua. Hariyono menuliskan bahwa sistem keluarga Tionghoa yang paternalistis menekankan kekuasaan dalam tangan ayah yang mengharuskan segala nilai dan aturan yang berlaku ditaati dan sulit berubah, bahkan cenderung menganut nilai "disiplin mati." Sistem keluarga seperti ini membuat suasana hubungan antara anak dan ayahnya cenderung kaku dan sangat formal. ${ }^{176}$ Dengan demikian, kelekatan yang aman antara anak kepada ayahnya cenderung lebih sulit terjadi.

Di sisi lain, dengan bertambahnya usia, pemuda dapat memiliki kelekatan juga dengan individu lain selain orang tuanya. ${ }^{177}$ Pada pemuda, teman kuliah, teman kerja, teman gereja, kekasih, atau pembina rohani di gereja dapat menjadi figur kelekatan yang signifikan selain ayah. Bagi pemuda yang telah menjalin hubungan romantis, ada kemungkinan figur kelekatan yang signifikan baginya saat ini adalah kekasihnya. ${ }^{178}$ Dengan mempertimbangkan figur kelekatan yang lain, tampaknya terdapat faktor lain yang mungkin dapat berhubungan lebih kuat dengan religiositas intrinsik pemuda jika dibandingkan dengan kelekatan dengan ayah.

Sementara itu, kelekatan pemuda-ibu menunjukkan adanya hubungan yang signifikan

${ }^{176}$ P. Hariyono, Kultur Cina dan Jawa: Pemahaman Menuju Asimilasi Kultural (Jakarta: Pustaka Sinar Harapan, 1993), 96-97.

\footnotetext{
${ }^{177}$ Trinke dan Bartholomew, "Hierarchies of Attachment Relationships," 604, 607.

${ }^{178}$ Ibid., 611.
} 
dengan religiositas intrinsik. Faktor ibu sebagai figur kelekatan yang utama tampaknya memang penting bagi pemuda dalam penelitian ini. Hal ini sejalan dengan temuan Campa dan kawan-kawan mengenai perilaku kelekatan dalam kehidupan dewasa muda yang menyebutkan bahwa ibu menempati posisi pertama sebagai figur kelekatan yang utama bagi pemuda. ${ }^{179}$

Tidak adanya hubungan yang signifikan antara dukungan iman orang tua-dari ayah dan ibu-dengan religiositas intrinsik pada pemuda dapat dijelaskan melalui beberapa hal. Dalam penelitian ini mayoritas responden masih tinggal bersama orang tua, namun ratarata responden mendapatkan dukungan iman yang relatif rendah dari ayah dan ibunya. Hal ini mungkin terjadi karena usia pemuda lebih banyak menghabiskan waktu di luar rumah dan jarang bersama-sama lagi dengan orang tua, misalnya karena kesibukan kuliah atau pekerjaan.

Faktor lain yang dapat menjelaskan hal tersebut yaitu kehadiran pendukung selain orang tua yang dapat berdampak terhadap religiositas intrinsik pemuda. Smith dan Snell menyebutkan bahwa kehadiran orang dewasa selain orang tua dalam gereja merupakan salah satu faktor yang berdampak pada komitmen religius pemuda. Semakin banyak sumber dukungan yang diperoleh pemuda dari orang dewasa lain di gerejanya, pemuda semakin dapat mempertahankan komitmen religiusnya. ${ }^{180}$ Responden dalam penelitian ini umumnya tergabung dalam persekutuan kelompok kecil di gereja sehingga komunitas dan pembina rohani di gereja dapat merupakan sumber dukungan yang utama bagi pemuda dibandingkan orang tua.

Dilihat dari tahap perkembangannya, pemuda berada pada tahapan iman individualistisreflektif. ${ }^{181}$ Pada tahap ini, pemuda telah menentukan sendiri keyakinan, nilai-nilai, dan 293.

${ }^{179}$ Campa, Hazan, dan Wolfe, "The Form and Function,"

\footnotetext{
${ }^{180}$ Smith dan Snell, Souls in Transition, 233-234.

${ }^{181}$ Fowler, Stages of Faith, 151-172.
}

komitmen religius yang dihidupinya setelah melalui pengujian dan analisis kritis serta reflektif terhadap keyakinan imannya. Dengan demikian, kemungkinan besar responden telah memiliki religiositas yang didasari komitmen intrinsik yang terbentuk dalam proses perkembangan imannya terlepas dari faktor orang tua sebagai sumber dukungan iman.

\section{KESIMPULAN}

Berdasarkan hasil penelitian dapat disimpulkan bahwa terdapat hubungan antara kelekatan pemuda-ibu dengan religiositas intrinsik, namun tidak terdapat hubungan antara kelekatan pemuda-ayah dengan religiositas intrinsik maupun dukungan iman orang tua dengan religiositas intrinsik pada pemuda di gereja Injili di Kota Bandung.

Tidak adanya hubungan antara kelekatan pemuda-ayah dan dukungan iman orang tua dengan religiositas intrinsik dapat dijelaskan melalui berbagai faktor, yaitu tidak diketahuinya informasi mengenai religiositas ayah dan kesamaan keyakinan pemuda dengan ayahnya, dampak nilai-nilai dalam sistem keluarga Tionghoa pada mayoritas responden, serta adanya kemungkinan figur kelekatan selain ayah yang lebih berperan terhadap religiositas intrinsik pemuda. Faktor pendukung lain seperti komunitas di gereja meliputi temanteman dan hamba Tuhan di gereja juga kemungkinan berperan penting bagi religiositas intrinsik pemuda. Selain itu, faktor perkembangan iman pemuda sendiri turut berdampak terhadap religiositas intrinsiknya. Sedangkan kelekatan pemuda-ibu berhubungan dengan religiositas intrinsik yang mungkin terjadi karena responden memiliki kelekatan aman dan mengembangkan rasa aman juga dalam perkembangan identitas religiusnya.

\section{DAFTAR KEPUSTAKAAN}

Ainsworth, Mary D. "Attachments Beyond Infancy." The American Psychologist 44, no. 4 (April 1989): 709-716.

Allport, Gordon W. "Behavioral Science, Religion, and Mental Health.” Journal of 
Religion and Health 2, no. 3 (1963): 187197. https://doi.org/10.1007/BF01533333.

Armsden, G. C., dan M. T. Greenberg. "The Inventory of Parent and Peer Attachment: Individual Differences and Their Relationship to Psychological WellBeing in Adolescence." Journal of Youth and Adolescence 16, no. 5 (Oktober 1987): 427-454.

Arndt, William, F. Wilbur Gingrich, Frederick

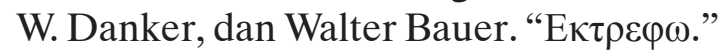
A Greek-English Lexicon of The New Testament and Other Early Christian Literature. Chicago: University of Chicago Press, 1979.

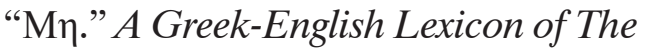
New Testament and Other Early Christian Literature. Chicago: University of Chicago Press, 1979.

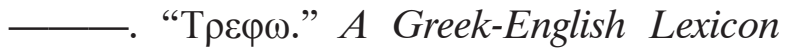
of The New Testament and Other Early Christian Literature. Chicago: University of Chicago Press, 1979.

Arnett, Jeffrey Jensen. "Emerging Adulthood: Understanding The New Way of Coming of Age." Dalam Emerging Adults in America Coming of Age in The 21st Century, diedit oleh Jeffrey Jensen Arnett dan Jennifer Lynn Tanner, 3-20. Washington: American Psychological Association, 2006.

Emerging Adulthood: The Winding Road from The Late Teens Through The Twenties. New York: Oxford University Press, 2004.

Arnold, Clinton E. Ephesians. Zondervan Exegetical Commentary Series on The New Testament v. 10. Grand Rapids: Zondervan, 2010.

Bao, Wan-Ning, Les B. Whitbeck, Danny R. Hoyt, dan Rand D. Conger. "Perceived Parental Acceptance As A Moderator of Religious Transmission Among Adolescent Boys and Girls." Journal of Marriage and Family 61, no.
2 (Mei 1999): 362-374. https://dx.doi. org/10.2307/353754.

Block, Daniel I. Deuteronomy. The NIV Application Commentary. Grand Rapids: Zondervan, 2012.

"Marriage and Family in Ancient Israel." Dalam Marriage and Family in The Biblical World, disunting oleh Ken M. Campbell. Downers Grove: InterVarsity, 2003.

Bowlby, John. Attachment and Loss. 2nd ed. New York: Basic Books, 1982.

Brelsford, Gina M., dan Annette Mahoney. "Spiritual Disclosure Between Older Adolescents and Their Mothers." Journal of Family Psychology 22, no. 1(2008): 62-70. https://doi.org/10.1037/0893-3200.22.1.62.

Bunge, Marcia J. "Biblical and Theological Perspectives on Children, Parents, and "Best Practices" for Faith Formation: Resources for Child, Youth, and Family Ministry Today." Dialog 47, no. 4 (Desember 2008): 348-360. https://doi. org/10.1111/j.1540-6385.2008.00414.x.

Campa, Mary I., Cindy Hazan, dan Jared E. Wolfe. "The Form and Function of Attachment Behavior in The Daily Lives of Young Adults." Social Development 18, no. 2 (Mei 2009): 288-304. https://doi. org/10.1111/j.1467-9507.2008.00466.x.

Christensen, Duane L. Deuteronomy 1 - 11. Disunting oleh David A. Hubbard, Glenn W. Barker, dan Bruce Manning Metzger. Word Biblical Commentary. Waco: Word, 1991.

Clinton, Timothy E., dan Gary Sibcy. Attachments: Why You Love, Feel, and Act The Way You Do: Unlock The Secret to Loving and Lasting Relationships. Brentwood: Integrity, 2002.

Craigie, Peter C., ed. The Book of Deuteronomy. The New International Commentary on The Old Testament. Grand Rapids: Eerdmans, 1976. 
Dollahite, David C., dan Jennifer Y. Thatcher. "Talking About Religion: How Highly Religious Youth and Parents Discuss Their Faith." Journal of Adolescent Research 23, no. 5 (September 2008): 611-641. https:// doi.org/10.1177/0743558408322141.

Donahue, Michael J. "Intrinsic and Extrinsic Religiousness: Review and MetaAnalysis." Journal of Personality and Social Psychology48,no.2(1985):400-419.https:// doi.org/10.1037/0022-3514.48.2.400.

Edwards, Jonathan. Religious Affections: A Christian's Character Before God. Disunting oleh J. M Houston. Vancouver: Regent College, 2003.

Flor, Douglas L., dan Nancy F. Knapp. "Transmission and Transaction: Predicting Adolescents' Internalization of Parental Religious Values." Journal of Family Psychology15,no.4(2001):627-645.https:// doi.org/10.1037/0893-3200.15.4.627.

Fowler, James W. Stages of Faith: The Psychology of Human Development and The Quest for Meaning. 1st ed. San Francisco: Harper \& Row, 1981.

Garland, Diana S. R. Family Ministry: $A$ Comprehensive Guide. Downers Grove: InterVarsity, 1999.

Gorsuch, Richard L. "Toward Motivational Theories of Intrinsic Religious Commitment." Journal for the Scientific StudyofReligion 33, no.4(Desember 1994): 315-325. https://doi.org/10.2307/1386491.

Gorsuch, Richard L., dan Susan E. McPherson. "Intrinsic/Extrinsic Measurement: I/ERevised and Single-Item Scales." Journal for the Scientific Study of Religion 28, no. 3 (September 1989): 348. https://doi. org/10.2307/1386745.

Granqvist, Pehr. "Attachment and Religiosity in Adolescence: Cross-Sectional and Longitudinal Evaluations." Personality and Social Psychology Bulletin 28, no. 2 (Februari 1, 2002): 260-270. https://doi. org/10.1177/0146167202282011.
- "Religiousness and Perceived Childhood Attachment: On the Question of Compensation or Correspondence." Journal for the Scientific Study of Religion 37, no. 2 (Juni 1998): 350. https://doi. org/10.2307/1387533.

Hamilton Jr., James M. "That The Coming Generation Might Praise The Lord: Family Discipleship in The Old Testament." Dalam Trained In The Fear of God, disunting oleh Randy Pinson dan Timothy P. Jones, 33-43. Grand Rapids: Kregel, 2011.

Hariyono, P. Kultur Cina dan Jawa: Pemahaman Menuju Asimilasi Kultural. Jakarta: Pustaka Sinar Harapan, t.t.

Harris, R. Laird, Gleason L. Archer, dan Bruce K. Waltke, ed. "Mûsār." Theological Wordbook of The Old Testament. Chicago: Moody, 1980.

Hoehner, Harold W. Ephesians: An Exegetical Commentary. Grand Rapids: Baker Academic, 2002.

Hoge, Dean R., Gregory H. Petrillo, dan Ella I. Smith. "Transmission of Religious and Social Values from Parents to Teenage Children." Journal of Marriage and Family 44, no. 3 (1982): 569-580. https://doi. org/10.2307/351580.

Kim, Seong Eun. "The Relationship of Parental Attachment and Christian Spirituality with Intergenerational Conflict Between Korean-American Young Adults and Their Parents." Journal of Psychology \& Theology 41, no. 3 (September 2013): 189-199. https://doi. org/10.1177/009164711304100302.

Kinnaman, David.YouLostMe.Diterjemahkan oleh Denny Pranolo. Bandung: Visi, 2012.

Klemer, Richard H. Marriage and Family Relationships. New York: Harper \& Row, 1970.

Lawrence, Jeanette A., dan Joan Valsiner. "Conceptual Roots of Internalization: 
From Transmission to Transformation.” Human Development 36, no. 3 (1993): 150 167. https://doi.org/10.1159/000277333.

Lefkowitz, Eva S. “Things Have Gotten Better': Developmental Changes Among Emerging Adults After the Transition to University." Journal of Adolescent Research 20, no. 1 (Januari 2005): 40-63. https:// doi.org/10.1177/0743558404271236.

Leonard, Kathleen C., Kaye V. Cook, Chris J. Boyatzis, Cynthia N. Kimball, dan Kelly S. Flanagan. "Parent-Child Dynamics and Emerging Adult Religiosity: Attachment, Parental Beliefs, and Aith Support." Psychology of Religion and Spirituality 5, no. 1 (2013): 5-14. https://doi.org/10.1037/ a0029404.

Lincoln, Andrew T. Ephesians. Word Biblical Commentary 42. Dallas: Word, 2005.

Longman III, Tremper. "Family in The Wisdom Literature." Dalam Family in The Bible: Exploring Custom, Culture, and Context, disunting oleh Richard S. Hess dan M. Daniel Carroll R., 80-99. Grand Rapids: Baker Academic, 2003.

McConville, J. G. Deuteronomy. Apollos Old Testament Commentary 5. Downers Grove: InterVarsity, 2002.

Merrill, Eugene H. Deuteronomy. The New American Commentary v. 4. Nashville: Broadman \& Holman, 1994.

Meyers, Carol. "The Family in Early Israel." Dalam Families in Ancient Israel, disunting oleh Leo G. Perdue. 1st ed. The Family, Religion, and Culture. Louisville: Westminster John Knox, 1997.

Miller, Patrick D. "That The Children May Know: Children in Deuteronomy." Dalam The Child in The Bible, disunting oleh Marcia J. Bunge, Terence E. Fretheim, dan Beverly R. Gaventa. Grand Rapids: William B. Eerdmans, 2008.
Nelson, Richard. Deuteronomy: $A$ Commentary. Louisville: Westminster John Knox, 2004.

O'Brien, Peter T. Surat Efesus. Diterjemahkan oleh Andri Kosasih. Surabaya: Momentum, 2013.

Pearce, Lisa D., dan Arland Thornton. "Religious Identity and Family Ideologies in the Transition to Adulthood." Journal of Marriage and Family 69, no. 5 (Desember 2007): 1227-1243. https://doi. org/10.1111/j.1741-3737.2007.00443.x.

Raja, Shyamala N., Rob McGee, dan Warren R. Stanton. "Perceived Attachments to Parents and Peers and Psychological Well-Being in Adolescence." Journal of Youth and Adolescence 21, no. 4 (Agustus 1992): 471-485.

Riesenfeld. " $\pi \alpha \rho \alpha . "$ Disunting oleh Gerhard Kittel. Diterjemahkan oleh Geoffrey W. Bromiley. Theological Dictionary of The New Testament. Grand Rapids: Eerdmans, 1967.

Ross, Richard. Student Ministry and The Supremacy of Christ. Bloomington: Crossbooks, 2009.

Samuolis, Jessica, Kiera Layburn, dan Kathleen M. Schiaffino. "Identity Development and Attachment to Parents in College Students." Journal of Youth and Adolescence 30, no. 3 (Juni 1, 2001): 373-384. https://doi. org/10.1023/A:1010448313516.

Sanchez, Edesio. "Family in The NonNarrative Sections of The Pentateuch." Dalam Family in The Bible: Exploring Custom, Culture, and Context, disunting oleh Richard S. Hess dan M. Daniel Carroll R., 32-58. Grand Rapids: Baker Academic, 2003.

Scharf, Miri, Ofra Mayseless, dan Inbal Kivenson-Baron. 'Adolescents' Attachment Representations and Developmental Tasks in Emerging Adulthood." Developmental Psychology 
40, no. 3 (2004): 430-444. https://doi. org/10.1037/0012-1649.40.3.430.

Schwartz, Kelly D. "RESEARCH: Transformations in Parent and Friend Faith Support Predicting Adolescents' Religious Faith." International Journal for the Psychology of Religion 16, no. 4 (Oktober 2006): 311-326. https://doi. org/10.1207/s15327582ijpr1604_5.

Shafranske, Edward P. "Clinical Psychologists' Religious and Spiritual Orientations and Their Practice of Psychotherapy." Dalam Psychology of Religion: Personalities, Problems, Possibilities, disunting oleh H. Newton Malony, 549-560. Grand Rapids: Baker, 1991.

Smith, Christian, dan Patricia Snell. Souls in Transition: The Religious and Spiritual Lives of Emerging Adults. New York: Oxford University Press, 2009.
Snodgrass, Klyne. Ephesians. The NIV Application Commentary. Grand Rapids: Zondervan, 1996.

Trinke, Shanna J., dan Kim Bartholomew. "Hierarchies of Attachment Relationships in Young Adulthood." Journal of Social and Personal Relationships 14, no. 5 (Oktober 1, 1997): 603-625. https://doi. org/10.1177/0265407597145002.

Vermeer, Paul. "Religion and Family Life: An Overview of Current Research and Suggestions for Future Research." Religions 5, no. 2 (April 14, 2014): 402421. https://doi.org/10.3390/rel5020402.

Wright, Christopher J. H. Deuteronomy. New International Biblical Commentary 4. Peabody: Hendrickson, 1996. 